\title{
Transcriptional Regulation in Rocket Leaves as Affected by Salinity
}

\author{
Giulia Franzoni ${ }^{1, *(\mathbb{D}}$, Giacomo Cocetta $^{1, * \mathbb{C}}$, Alice Trivellini ${ }^{2}\left(\mathbb{D}\right.$ ) and Antonio Ferrante ${ }^{1(\mathbb{C})}$ \\ 1 Department of Agricultural and Environmental Sciences, Università degli Studi di Milano, via Celoria 2, \\ 20133 Milano, Italy; antonio.ferrante@unimi.it \\ 2 Institute of Life Sciences, Scuola Superiore Sant'Anna, Pz. Martiri della Libertà 33, 56127 Pisa, Italy; \\ A.trivellini@santannapisa.it \\ * Correspondence: giulia.franzoni@unimi.it (G.F.); giacomo.cocetta@unimi.it (G.C.)
}

Received: 20 November 2019; Accepted: 20 December 2019; Published: 23 December 2019

\begin{abstract}
Salinity is one of the major abiotic stress causing yield losses and decreasing product quality. The beneficial effects of biostimulant products to enhance plant tolerance to abiotic stresses have been reported in several crops, but their mode of action is poorly understood. This work aims to better understand the effect of salt stress on wild rocket treated with a borage extract. The expression of some of the transcription factors (TFs) typically involved in salt stress response was studied within a $24 \mathrm{~h}$ period. Physiological parameters such as chlorophyll, chlorophyll $a$ fluorescence, carotenoids, phenols, and anthocyanin were analyzed. Results obtained showed that salt stress induced a general increase in the expression levels of almost all TFs studied, whereas the treatment with the plant-base extract only induced an increase at specific time points. Moreover, the approach adopted allowed indagating the change in gene expression during time. Different pathways such as sugars metabolism, cuticular wax biosynthesis, and brassinosteroids signaling took part in plant responses.
\end{abstract}

Keywords: borage extract; Diplotaxis tenuifolia L.; salt stress; transcription factors

\section{Introduction}

Salinity stress is a major abiotic stress affecting plant growth, quality, and productivity. More than $30 \%$ of the irrigated land of the world is affected by salinization and this number was projected to increase considering the climate change scenario and the environmental pollution [1,2]. Therefore, the study of the physiological and molecular mechanisms of tolerance to salt stress is crucial to obtain crops able to survive without loss of productivity under stressful conditions.

It is known that salt stress impairs plants 'performance for different reasons: it causes hyperosmotic stress, ion imbalance and, as consequence, oxidative damage. In the short term (after minutes, hours, and the first day of stress), salt stress is perceived by the roots as osmotic stress caused by the reduced ability of the plants to take up water. In the long term (days, weeks, or years), plant growth is limited by the ion toxicity and nutrient imbalance occurring in the cytoplasm due to the accumulation of salt and the competitive uptake mechanisms with other ions. The first phase, when the salt has not penetrated in plant tissues, is also known as the water-deficit effect of salinity and the cellular and metabolic processes involved are in common with drought stress. The second phase is the salt-specific effect and it is due to the excess of ions inside the plant [3].

Several metabolic processes such as photosynthesis [4,5], respiration [6], phytohormones regulation [7], and protein biosynthesis can be altered by salinity. The effects of the stress on plants vary depending on different factors, such as the level of salt concentration, the duration of the exposure, the phenological stage, the interaction with the environmental conditions, and the ability of a species or cultivar to grow in saline condition. According to this ability, plants are generally divided 
into glycophytes and halophytes. Glycophytes growth is inhibited by concentrations of $\mathrm{NaCl}$ around 100-200 mM, whereas halophytes can survive at higher concentrations of $\mathrm{NaCl}$, typically around 300-500 mM [8]. The threshold value used as criteria to define if a plant belongs to glycophytes or halophytes changed during time and according to different authors. For instance, Flowers et al. [9] initially proposed a value of $300 \mathrm{mM}$ and then $200 \mathrm{mM}$, whereas other authors referred to a lower threshold about $85 \mathrm{mM}$ [10]. This situation has led to a confusion in the number of the species belonging to one or the other categories.

Wild rocket (Diplotaxis tenuifolia L.) is a perennial plant grown in the Mediterranean basin present in coastal areas that has been recently classified as salt tolerant with potential as vegetable crops for saline agriculture. De Vos et al. [11] investigated the responses of this species under the effects of increasing salinity and they observed that no growth reduction appeared at up to $100 \mathrm{mM} \mathrm{NaCl}$ and a decrease about $20 \%$ occurred at $200 \mathrm{mM}$, mostly due to the modifications in leaf morphology rather than salt toxicity. Moreover, rocket plants were able to survive at concentrations of around $300 \mathrm{mM}$.

Tolerant plants are able to use different adaptation strategies including morphological, physiological, biochemical, and molecular changes in order to cope with the salinity stress and complete their growing cycle. Salt stress is primarily perceived by the roots and the two main strategies that plants adopt for salt tolerance are the minimization of the uptake of salt by the roots and its distribution in all tissues in order to avoid the accumulation in the leaves [12]. During the osmotic-stress phase, plant growth in saline condition seems to be regulated by hormonal regulation. Among the different plant hormones, abscisic acid (ABA) is the main candidate in this mechanism since it is present in xylem sap and it increases after drought and salt stress. In the second phase, specific mechanisms controlling $\mathrm{Na}^{+}$and $\mathrm{Cl}^{-}$concentrations occur, such as the exclusion of salt from the phloem, its accumulation in the older leaves, in the leaf base or stems, and its compartmentalization in the vacuoles.

Shavrukov [13] pointed out the differences between salt stress and salt shock, considering salt concentration and exposure. Salt shock is considered as an extreme form of salt stress and is defined as the sudden exposition of plants to high levels of $\mathrm{NaCl}$. This situation rarely occurs in natural or agricultural system where the $\mathrm{NaCl}$ increases gradually, but it is still applied in plant studies of salt stress responses. The osmotic and the ionic component can be also distinguished in salt shock, albeit with some differences. Indeed, when the plants are exposed to salt shock, they have to face a large difference in the osmotic pressure, causing plasmolysis and the leakage of the nutrient solution in the apoplast. Genes involved in the osmotic responses are rapidly activated in roots cells. During this phase the plants are not able to control the movement of the solutes and salt is quickly transported from the roots to the leaves.

Plant response to abiotic stresses can be described as a complex regulatory network involving different physiological pathways and interactions among signaling molecules, defense proteins, and stress-responsive genes [14]. Tolerant plants may have some peculiar stress-responsive genes which are not present in susceptible plants. Therefore, most of the research is focused on the identification of these salt tolerance associated genes and their role in the molecular mechanisms of tolerance. These genes encode various salt stress responsive proteins and transcription factors (TFs). The first ones act directly against salt stress by protecting the plants from the dehydration and regulating the biosynthesis of osmo-protectants, while the latter are involved in the regulation of the gene expression and the signal transduction.

TFs have different domains, a transcriptional domain and DNA binding domains. TFs bind to specific cis regulating DNA sequence modulating the expression of salt-responsive genes. Several TFs share the same binding domain and on the basis of this sequence they are classified in families, such as NAM-ATAF1.2-CUC (NAC), APETALA2/Ethylene Responsive Factor (AP2/ERF), Basic Leucine Zipper Domain (bZIP), MYB, and WRKY [15]. Cavaiuolo et al. [16] performed a transcriptomic analysis of short-term acclimation in Diplotaxis tenuifolia L. after salt shock exposition and identified 20879 active genes and 12995 silent genes in response to stressful conditions. Among these, 29 TFs were 
upregulated and 44 downregulated under salinity, with NAC, AP2/ERF, and bZIP families being the most represented.

The study of TFs role, their regulation, and the target genes represents one of the modern genetic engineering strategies to improve crop tolerance against abiotic stresses. TFs are considered to be a good target since most of them are early responsive genes under stress condition and they are able to control a set of genes involved in plant stress resistance $[17,18]$. This approach reveals the complexity of transcriptional regulation networks of plant genes since an overlap in the TFs expression in responses to multiple abiotic stresses often appears. Indeed, besides the regulation of stress responses, TFs participate in different biological and physiological processes, such as plant development or senescence, regulating a cluster of downstream target genes $[19,20]$. Thus, linking specific TFs with a single stress response in a big network of pathways is a big challenge.

Beside the study of plants stress responses mechanisms, transcriptome analysis is a strategy more frequently used to understand the effects and the mode of action of biostimulants on plants [21-24].

The object of this study was to evaluate the response of Diplotaxis tenuifolia L. to salt stress and the effect of an aqueous borage extract as biostimulant treatment to counteract salinity stress. The expression of some of the TFs typically involved in salt stress response was studied. Moreover, plant response was analyzed in terms of change in different physiological parameters, such as chlorophyll, chlorophyll $a$ fluorescence, carotenoids, phenols, and anthocyanins. The borage extract used in this experiment showed positive effect both on primary and secondary metabolism of lettuce and rocket plants grown under non-stressful conditions in previous experiments [25].

\section{Results}

\subsection{Gene Expression Analysis}

The quality and concentration of RNA extracted from rocket leaves subjected to salt stress and treated with borage extract were measured using the NanoDrop instrument. On average, the A260/280 ratio of RNA samples was 2.30 and the ratio of A260/230 was 2.20, indicating that the RNA was not contaminated by proteins or phenols.

Selected primers were preliminary tested in a qRT-PCR in order to check if they bind and amplify the RNA via melting curve analysis. The results obtained showed that all primers worked successfully.

The changes in the expression of the transcription factors involved in the salt stress response are clustered into a heatmap (Figure 1). The results of statistical analysis and the graphs representing the expression analysis of each transcription factor are reported in the Supplementary Table S1 and Figures S1-S11. Different trends in the transcript levels were found in response to salt stress, borage treatment, and over time. Under no stress condition a similar pattern of expression was observed for DtRD29A, $D t b H L H 122, D t N A C 72, D t N A C 29, D t C 3 H 49$, and DtRABC2B with a progressive decrement within $24 \mathrm{~h}$. Their trends did not change in response to borage treatment. The minimum level was observed for $D t N A C 29$ after $9 \mathrm{~h}$ and for $D t R A B C 2 B$ after $24 \mathrm{~h}$. In contrast, a constant increment of the expression levels was observed for $D t D R E B 2 A$ and $D t H B 7$ within $9 \mathrm{~h}$. After $24 \mathrm{~h}$ the expression of almost all of TFs was downregulated in plants grown under non-stress condition, regardless of the treatment. In contrast, stressful growing condition induced a general increase in the expression levels of TFs, as shown by the abundance of the red color in the right side of the heatmap (Figure 1). In particular, an induction of the expression levels was observed in response to salt stress after $6 \mathrm{~h}$ and $9 \mathrm{~h}$. 


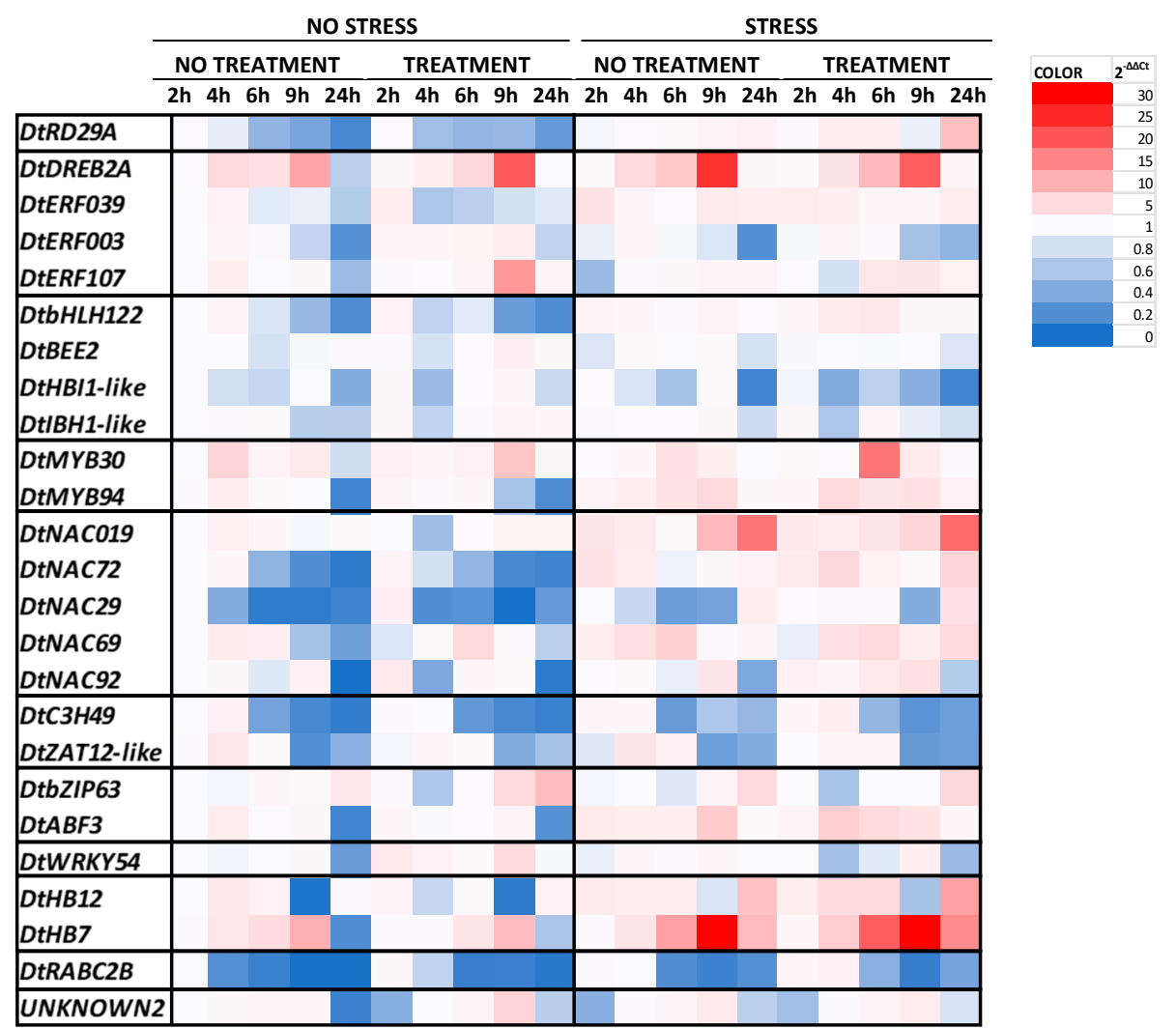

Figure 1. Heatmap showing temporal expression $\left(2^{-\Delta \Delta C t}\right)$ of selected transcription factors associated with salt stress responses in rocket plants grown under salt stress condition and treated with a borage extract. The rows represent the transcription factors and within each row, the blue shaded areas indicate downregulated gene expression, whereas the red shaded areas indicate upregulated gene expression.

A constant decrease in the expression levels of $D t R D 29 A$ was found in non-stressed leaves within $24 \mathrm{~h}$, both in treated and control plants. An opposite trend was detected in rocket grown under salt stress conditions; a gathering but slight increase was observed in control plants, whereas the expression of $D t R D 29 A$ rose faster in plants treated with borage extract. In particular, a constant increase was observed within $6 \mathrm{~h}$, followed by a decrease at $9 \mathrm{~h}$ and a final growth after $24 \mathrm{~h}$. At this time point, the $2^{-\Delta \Delta \mathrm{Ct}}$ value of treated plants was almost eight times larger than the initial point (non-stressed and non-treated at $2 \mathrm{~h}$ ).

The gene expression of the selected transcription factors belonging to AP2/ERF family showed different patterns in response to the experimental conditions. The expression levels of DtDREB2A increased within $9 \mathrm{~h}$ and decreased at $24 \mathrm{~h}$ in untreated and unstressed plants. This trend did not change in response to the application of the borage treatment or after the exposition to high salinity. Only few differences appeared in specific time points. In particular, the expression was higher $(+72 \%)$ in plants treated with borage extract at $9 \mathrm{~h}$ under no stress condition if compared with the control ones at the same time point. In contrast, the highest level was reached in control plants grown under salt stress condition, and the expression resulted almost 24-fold higher than the calibrator (non-stressed and non-treated at $2 \mathrm{~h}$ ).

The expression levels of DtERF107 and DtERF039 in unstressed and untreated plants were generally low. The expression of DtERF107 did not change in response to borage treatment, except after $9 \mathrm{~h}$ where the $2^{-\Delta \Delta \mathrm{Ct}}$ value increased more than 12 times. Salt stress slightly induced the accumulation of DtERF039 mRNA in all samples, regardless of the treatment.

$D t E R F 003$ expression levels were very low in control plants both under non-stressed and stressed conditions. Two different trends emerged in plants treated with the borage extract depending on the stress condition. In particular, under optimal condition borage treatment led to three times increase 
in the expression levels by within $9 \mathrm{~h}$, whereas salt stress generally lowered all values and the trend observed in treated plant was similar to that of control.

The expression levels of selected transcription factors belonging to the bHLH family were very low and only few differences were observed in response to stress or borage treatment. The expression of DtbHLH122 in control plants grown under non-stressful conditions was double at $4 \mathrm{~h}$ compared with the control, then constantly decreased after $24 \mathrm{~h}$. Borage treatment affected the trend anticipating the peak at $2 \mathrm{~h}$. Salt stress generally induced the expression of this TF, mostly after 4 and $6 \mathrm{~h}$ in plants treated with borage extract.

No change was observed in the expression of DtBEE2 in response to stress or treatment, only a slight increase was detected in non-stressed and treated plants after $9 \mathrm{~h}$.

Different patterns were detected in the expression of DtHBI1-like. In particular, a constant decrease to 0.2 was observed within $24 \mathrm{~h}$ in response to salt stress both in control and in treated plants. No clear effect related to salt stress, time, or treatment appeared in the expression of DtIBH1-like.

Under non-stressful condition the expression of DtMYB30 in control plants was similar to the calibrator and only a peak appeared at $4 \mathrm{~h}$. In plants treated with borage extract the expression increased within $9 \mathrm{~h}$ reaching the $2^{-\Delta \Delta \mathrm{Ct}}$.value of 7.4 , then decreased at $24 \mathrm{~h}$. Salt stress did not affect the expression of DtMYB30, only a peak in the expression appeared in combination with borage treatment after $6 \mathrm{~h}$. The expression levels of DtMYB94 in control plants showed a similar pattern of those observed in the expression of DtMYB30 with an increase at $4 \mathrm{~h}$ followed by a constant decrease up to 0.2 at $24 \mathrm{~h}$. Similar trend was found also in plants treated with borage extract. Salt stress generally induced the expression levels mostly after 4, 6, and $9 \mathrm{~h}$, both in non-treated and treated samples.

Different expression patterns were found in response to the experimental condition from the analysis of the TFs belonging to the NAC family. As previously mentioned, a constant decrease was observed within $24 \mathrm{~h}$ in the expression levels of DtNAC29 and DtNAC72 of plants grown under non-stressful condition, regardless the treatment. Under salt stress they showed two different trends. In particular, within $9 \mathrm{~h}$ the salt stress did not affect the expression of DtNAC29 in untreated plants while the expression slightly increased in treated plants. After $24 \mathrm{~h}$ the expression levels increased by four and three times, in treated and non-treated samples, respectively. The expression of DtNAC72 was induced four times after $2 \mathrm{~h}$ of stress in control plants. Afterwards, the amount of transcript decreased within $6 \mathrm{~h}$ and slightly increased at $24 \mathrm{~h}$. The expression of DtNAC69 in untreated and unstressed plants increased more than three times at $4 \mathrm{~h}$, then progressively decreased within $24 \mathrm{~h}$. The accumulation of the transcripts was not affected by the borage treatment, except after $6 \mathrm{~h}$, when a peak more than five times higher appeared. In contrast, salt stress generally induced their accumulation. The expression levels of DtNAC92 in control plants grown under non-stressed condition increased more than double within $9 \mathrm{~h}$ and subsequently decreased at $24 \mathrm{~h}$. The expression levels of DtNAC019 were similar to those observed in DtRD29A. Indeed, under non-stressed condition the expression did not change during time or in response to borage treatment. In contrast, salt stress induced a constant increase in all samples. In particular, values increased from a $2^{-\Delta \Delta C t}$.value of 4 to almost 18 after $24 \mathrm{~h}$ of exposure to salt stress.

A similar pattern of expression was observed for DtC3H49 and DtZAT12-like. In particular, $\mathrm{DtC} 3 \mathrm{H} 49$ was strongly downregulated after $6 \mathrm{~h}$ in all growing conditions, whereas after 2 and $4 \mathrm{~h}$ of salt stress exposition, the expression slightly increased both in control and in treated plants. In a similar way, DtZAT12-like expression was downregulated both under stress and non-stress conditions at $9 \mathrm{~h}$ and $24 \mathrm{~h}$.

The expression of $D t A B F 3$ was generally low and all values ranged from 1 to 3 within $9 \mathrm{~h}$ in plants grown under non-stressful condition. After $24 \mathrm{~h}$ the expression was downregulated, regardless of the borage treatment. Salt stress induced a general increase in the expression of $D t A B F 3$ within $9 \mathrm{~h}$. In general, no change was observed in the expression of DtbZIP63 within $6 \mathrm{~h}$, neither in control nor in treated plants and regardless of the growing conditions. Under non-stressful conditions, the expression of DtbZIP63 was three times higher at $24 \mathrm{~h}$ in control plants, whereas it was strongly upregulated 
in treated plants after $9 \mathrm{~h}$ and $24 \mathrm{~h}$ and the values were 5 and more than eight times higher than the calibrator.

The expression levels of DtWRKY54 in control plants were generally low within $24 \mathrm{~h}$, both in non-stressed and in stressed conditions. In contrast, borage treatment slightly induced its accumulation, mostly under a non-stress condition. After $2 \mathrm{~h}$ the $2^{-\Delta \Delta \mathrm{Ct}}$ value was three times higher than control but it constantly decreased during time, apart from a peak after $9 \mathrm{~h}$. Under salt stress the expression levels were reduced and the highest value of around 3 was found in treated plants after $9 \mathrm{~h}$ of exposure to high salinity.

The expression of both $D t H B 12$ and $D t H B 7$ increased in response to salt stress. In particular, the expression of $D t H B 12$ in plants grown under non-stressful condition did not change during time and the maximum level was reached in control plants after $4 \mathrm{~h}$. After $9 \mathrm{~h}$ the TF was downregulated, both in treated and control plants. The same effect was observed in plants grown under salinity. The maximum levels were reached after $24 \mathrm{~h}$ of exposure both in control and in treated plants; the values were eight and 12 times higher than the internal target, respectively. The expression pattern of $D t H B 7$ was very similar to those of DtHB12 in control and treated plants. Moreover, expression levels increased in response to salt stress, but the trend did not change. The maximum value was reached after $9 \mathrm{~h}$ of salt exposure and the expression was almost 30 times higher than the internal calibrator, both in control and in treated plants.

The expression levels of $D t R A B C 2 B$ in rocket leaves revealed a general downregulation within $24 \mathrm{~h}$. In particular, under non-stressed condition the $2^{-\Delta \Delta C t}$ value of control plants dropped to 0.2 after $4 \mathrm{~h}$ and reached the minimum point $(0.04)$ after $24 \mathrm{~h}$. A similar trend was found in plants grown under salt stress, even if the decrease started $2 \mathrm{~h}$ late. Plants treated with borage extract showed higher values, mostly in combination with salt stress.

The expression of an unknown transcription factors named Unknown 2 grew for the first $6 \mathrm{~h}$ in unstressed and untreated plants, then decreased to 0.6 at $24 \mathrm{~h}$. Borage treatment slightly led to a decrease of the expression level at $2 \mathrm{~h}$ whereas a peak almost seven times higher emerged after $9 \mathrm{~h}$. Under salt stress, both control and treated plants had the same trend excluding at $24 \mathrm{~h}$.

\subsection{Physiological Analyses}

\subsubsection{Chlorophyll}

The chlorophyll content measured in vivo did not show any significant change one day after the beginning of the stress (Figure 2a), not in response to salt, nor to borage treatment. All values were around 10 r.u. A significant interaction between stress and treatment was observed after two days of stress (Table S2). In particular, under a non-stress condition, the chlorophyll content of plants treated with borage extract was significantly lower than control while an opposite effect was found under a stress condition (Figure 2b). After four days (Figure 2c) chlorophyll content was similar in stressed plants (regardless of the treatment) and non-stressed plants treated with borage extract. However, their values were significantly lower than those observed in control plants grown without salt stress.

Chlorophyll content showed different trends during the experimental time course: under a non-stress condition, chlorophyll content increased in control plants from 10 r.u. to almost 15 r.u., while it did not change in plants treated with a borage extract. Stressed plants did not show any variation over time, only a slight increase was observed after two days in plant treated with borage extract (Figure 2b).

Chlorophyll concentration obtained with the destructive method (Figure 3) did not show the same trend of the in vivo analyses. In particular, no significant change appeared in chlorophyll $a+b$ concentration of rocket leaves after one and two days of stress (Figure $3 a$ and $b$ ) and the average values were around $1 \mu \mathrm{g} \mathrm{mg}^{-1} \mathrm{FW}$. In contrast, salt stress induced a significant decrease in the concentration of chlorophyll $a+b$ in plants treated with borage extract after four days of stress (Figure 3c). 


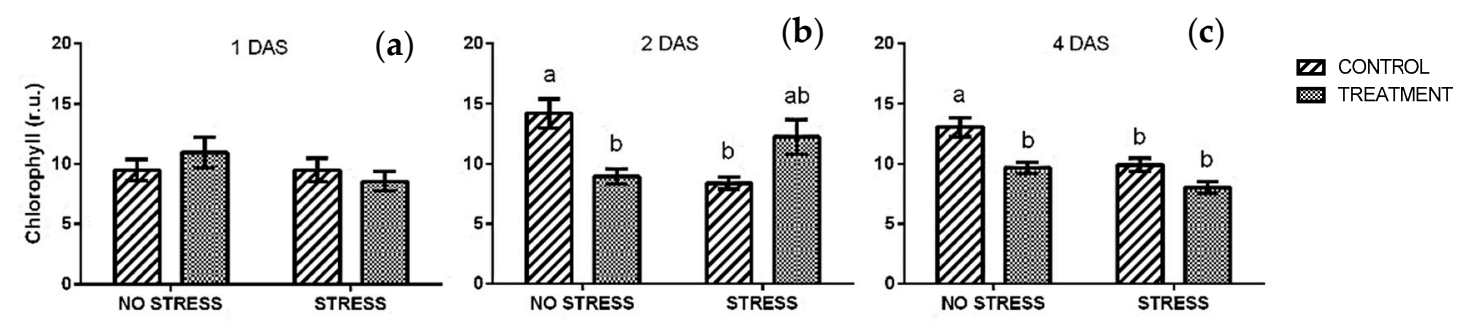

Figure 2. Chlorophyll content determined in vivo in rocket leaves treated with water (CONTROL) and with borage extract (TREATMENT) and subjected to salt stress $(200 \mathrm{mM})$. Measures were taken after one day (a), two days (b), and four days (c) of stress. Values are means \pm SE $(n=11)$. Data were subjected to two-way ANOVA. Different letters, where present, represent significant differences $(p<0.05)$.

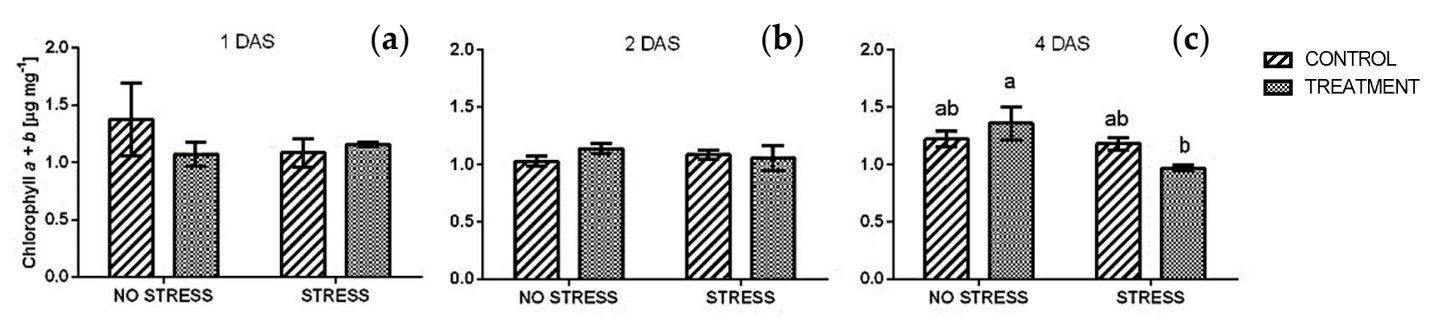

Figure 3. Chlorophyll $a+b$ concentration in rocket leaves treated with water (CONTROL) and with borage extract (TREATMENT) and subjected to salt stress $(200 \mathrm{mM})$. Measures were taken after one day $(\mathbf{a})$, two days $(\mathbf{b})$, and four days $(\mathbf{c})$ of stress. Values are means \pm SE $(n=4)$. Data were subjected to two-way ANOVA. Different letters, where present, represent significant differences $(p<0.05)$.

\subsubsection{Total Carotenoids}

The concentration of carotenoids (Figure 4 ) in rocket leaves showed the same trend observed in chlorophyll $a+b$ analyses. In particular, no significant change was detected after 1 and two days of stress and all values were similar to non-stressed control (Figure $4 a, b)$. After four days of stress, carotenoids level of plants treated with borage extract significantly decreased, while it did not change in control plants (Figure 4c).

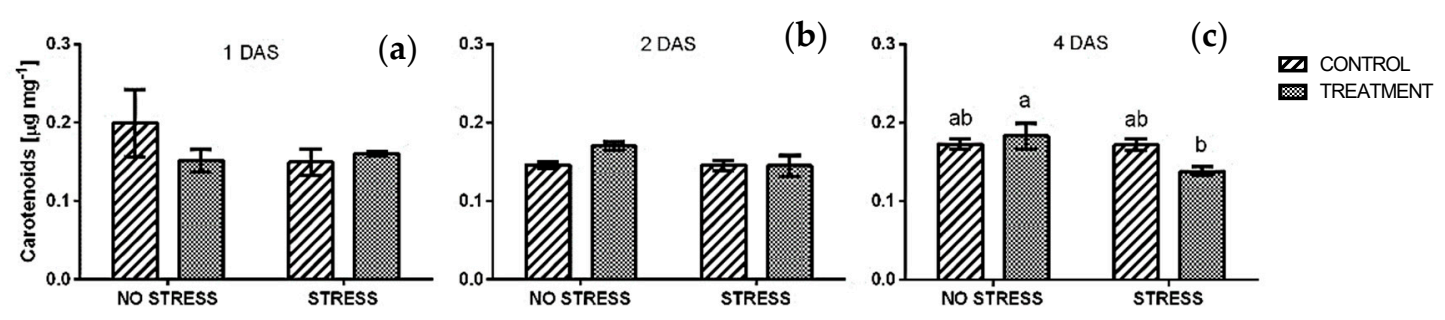

Figure 4. Carotenoids concentration in rocket leaves treated with water (CONTROL) and with borage extract (TREATMENT) and subjected to salt stress (200 mM). Measures were taken after one day (a), two days $(\mathbf{b})$, and four days (c) of stress. Values are means $\pm \mathrm{SE}(n=4)$. Data were subjected to two-way ANOVA. Different letters, where present, represent significant differences $(p<0.05)$.

\subsubsection{Phenolic Index and Anthocyanin}

Phenolic index and anthocyanin content measured in rocket leaves are listed in Table 1. Both parameters were not affected by the salt stress, in any of the time points analyzed. Moreover, statistical analysis did not detect any significant difference between samples in response to borage treatment (Table S2). 
Table 1. Phenolic index and anthocyanin concentration in rocket leaves treated with water (CONTROL) and with borage extract (TREATMENT) and subjected to salt stress $(200 \mathrm{mM})$. Measures were taken after one day, two days, and four days of stress. Values are means $\pm \mathrm{SE}(n=4)$. Data were subjected to two-way ANOVA. Different letters, where present, represent significant differences $(p<0.05)$.

\begin{tabular}{cccccccc}
\hline \multirow{2}{*}{ Stress } & \multirow{2}{*}{ Treatment } & \multicolumn{2}{c}{ Phenolic Index $\left[\mathbf{A B S}_{\mathbf{3 2 0} \mathbf{~ n m}} \mathbf{~}^{\mathbf{- 1}}\right.$ ] } & \multicolumn{3}{c}{ Anthocyanin [Cyanidin eq. mg/100 g] } \\
\cline { 3 - 8 } & & 1 DAS & 2 DAS & 4 DAS & 1 DAS & 2 DAS & 4 DAS \\
\hline NO STRESS & CONTROL & $19.67 \pm 2.15$ & $13.83 \pm 3.62$ & $20.00 \pm 1.88$ & $19.59 \pm 1.54$ & $19.31 \pm 2.02$ & $21.17 \pm 1.71$ \\
NO STRESS & TREATMENT & $19.87 \pm 0.86$ & $20.10 \pm 0.63$ & $19.06 \pm 0.79$ & $21.27 \pm 0.58$ & $20.91 \pm 0.44$ & $19.43 \pm 0.54$ \\
STRESS & CONTROL & $18.22 \pm 0.94$ & $17.58 \pm 0.86$ & $17.43 \pm 1.08$ & $19.45 \pm 0.26$ & $19.45 \pm 0.63$ & $19.22 \pm 0.77$ \\
STRESS & TREATMENT & $18.19 \pm 1.84$ & $16.45 \pm 1.18$ & $16.37 \pm 0.80$ & $18.74 \pm 1.67$ & $17.55 \pm 1.01$ & $18.00 \pm 0.87$ \\
\hline
\end{tabular}

\subsubsection{Chlorophyll a Fluorescence}

The maximum quantum efficiency of PSII ( Fv/Fm) gives an information on the plant's potential photosynthetic ability and can be used as stress marker since its sensitivity to different stressful conditions. Generally, an average value of 0.83 is considered the stress threshold for herbaceous plants, whereas lower values indicate stressful conditions for the plants with limitation of physiological processes [26]. A significant interaction between stress condition and treatment was observed after one day of stress (Table S2). Fv/Fm values were really close to the threshold in non-stressed plants and the same value was observed in control plants grown under salt stress. In contrast, stressed plants treated with borage extract had a lower value of about 0.73 (Figure 5a). After two and four days of stress (Figure $5 b, c$ ) the Fv/Fm ratio increased exceeded the 0.83 threshold, regardless of the stress condition or the treatment.
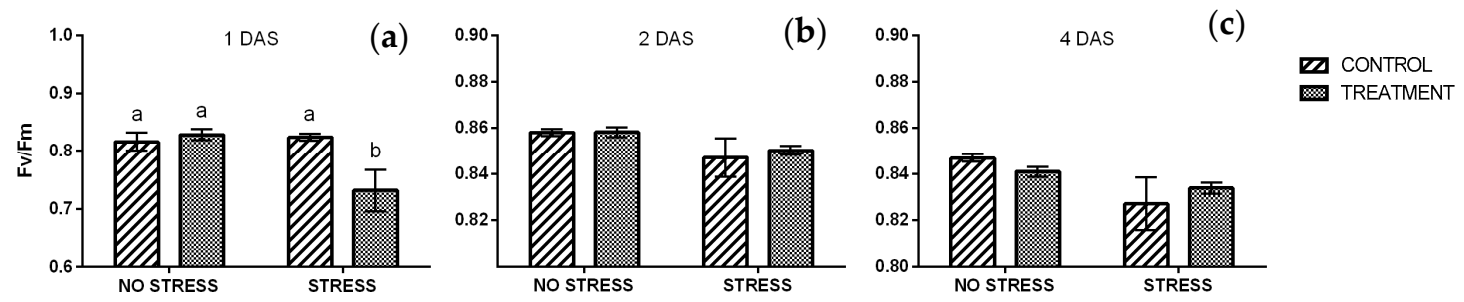

Figure 5. Maximum quantum efficiency of PSII (Fv/Fm) measured in rocket leaves treated with water (CONTROL) and with borage extract (TREATMENT) and subjected to salt stress (200 mM). Measures were taken one day (a), two days (b), and four days (c) of stress. Values are means \pm SE $(n=9)$. Data were subjected to two-way ANOVA. Different letters, where present, represent significant differences $(p<0.05)$.

The performance index (PI) did not show any significant change, not in response to salt stress, neither to treatment. After one day of stress (Figure 6a) the results had a similar trend to Fv/Fm ratio and stressed plants treated with borage extract had a lower value if compared with the other conditions. With the exception of this, all of the values averaged from 2.2 to 2.8. After two and four days of stress the PI increased in all samples and values averaged from 2.8 and 3.7 (Figure 6b,c). Salt stress significatively affected the PI, however no significant difference emerged among samples (Table S2). 

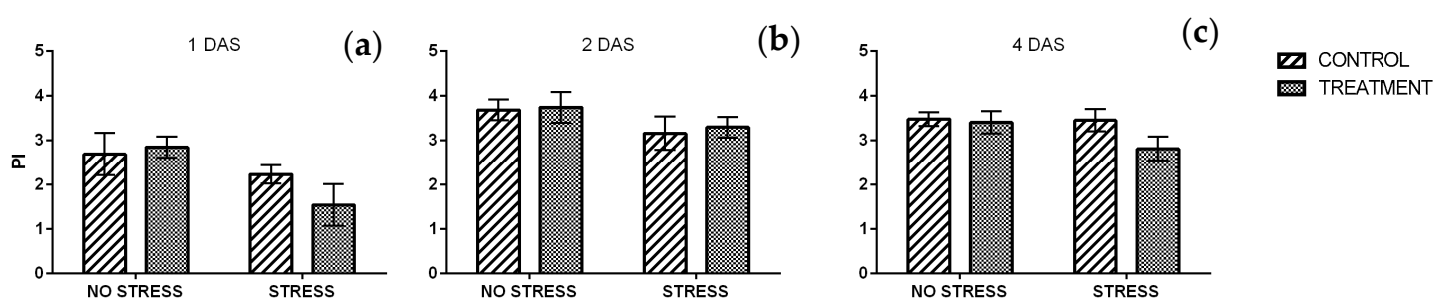

Figure 6. Performance index (PI) measured in rocket leaves treated with water (CONTROL) and with borage extract (TREATMENT) and subjected to salt stress $(200 \mathrm{mM})$. Measures were taken after one day (a), two days $(\mathbf{b})$, and four days $(\mathbf{c})$ of stress. Values are means \pm SE $(n=9)$. Data were subjected to two-way ANOVA. Different letters, where present, represent significant differences $(p<0.05)$.

\subsubsection{Nitrate}

In general, salinity significantly caused a decrease of the nitrate concentration in rocket leaves, regardless the treatment. After one day (Figure 7a) nitrate contents of non-stressed plants were 3836 and $4264 \mathrm{mg} \mathrm{kg}^{-1} \mathrm{FW}$ in control and after borage treatment, respectively. At the same time nitrate levels were halved under stress condition. In particular, nitrate concentrations were $1856 \mathrm{mg} \mathrm{kg}^{-1}$ FW in control plants and $2423 \mathrm{mg} \mathrm{kg}^{-1} \mathrm{FW}$ in plants treated with borage extract. A similar effect has been observed also after four days, while after two days, a significant interaction between stress and treatment was detected (Table S2).
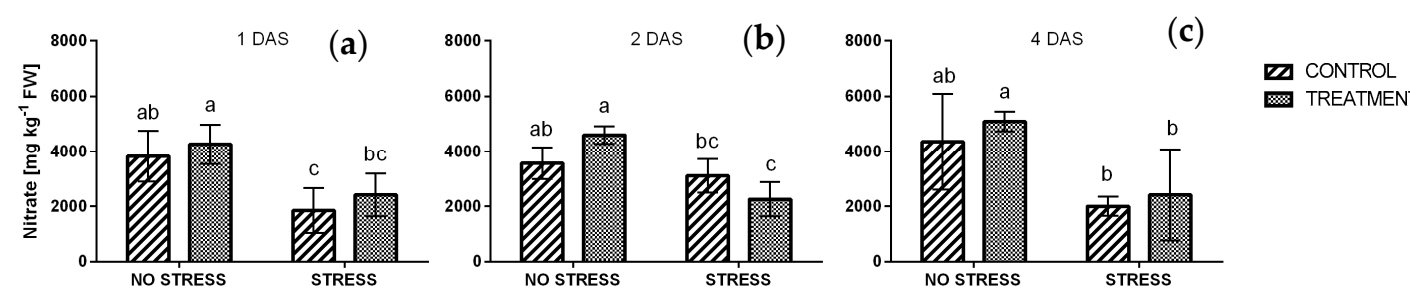

M TREATMENT

Figure 7. Nitrate concentration in rocket leaves treated with water (CONTROL) and with borage extract (TREATMENT) and subjected to salt stress (200 mM). Measures were taken after one day (a), two days $(\mathbf{b})$ and four days $(\mathbf{c})$ of stress. Values are means \pm SE $(n=4)$. Data were subjected to two-way ANOVA. Different letters, where present, represent significant differences $(p<0.05)$.

\subsubsection{Reducing and Total Sugars}

A significant effect of salinity was detected one day after the beginning of the stress (Figure 8a) when the average value of reducing sugars increased from $2.9 \mathrm{mg} \mathrm{g}^{-1} \mathrm{FW}$ in non-stress condition to $7.5 \mathrm{mg} \mathrm{g}^{-1} \mathrm{FW}$ under salt stress. A slight but not significant increase was also observed in non-stressed conditions, in response to borage treatment. After two and four days of stress the concentration of reducing sugars decreased and no significant differences were observed among samples. In particular, all values were similar to control plants grown in non-stressful condition and values ranged from 2.4 to $3.9 \mathrm{mg} \mathrm{g}^{-1} \mathrm{FW}$. A similar trend was found in the concentration of total sugars, as reported in Figure 9 . 
(a)

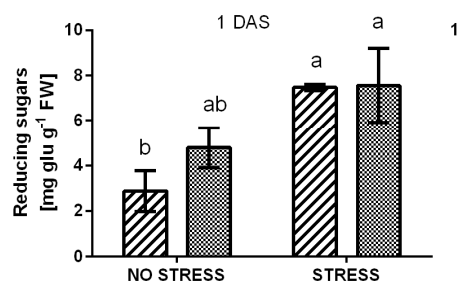

(b)

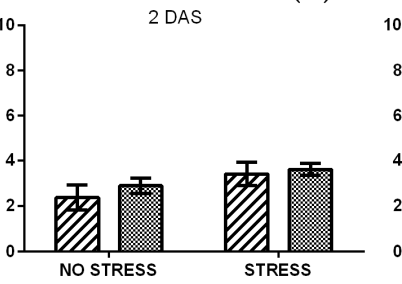

(c)

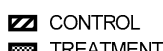

TREATMENT

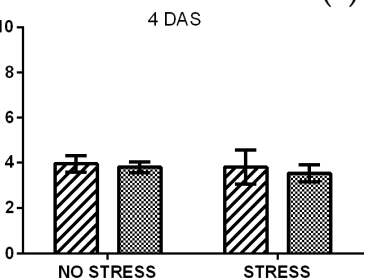

Figure 8. Reducing sugars concentration in rocket leaves treated with water (CONTROL) and with borage extract (TREATMENT) and subjected to salt stress for $24 \mathrm{~h}$. Measures were taken after one day (a), two days $(\mathbf{b})$ and four days $(\mathbf{c})$ of stress. Values are means \pm SE $(n=4)$. Data were subjected to two-way ANOVA. Different letters, where present, represent significant differences $(p<0.05)$.
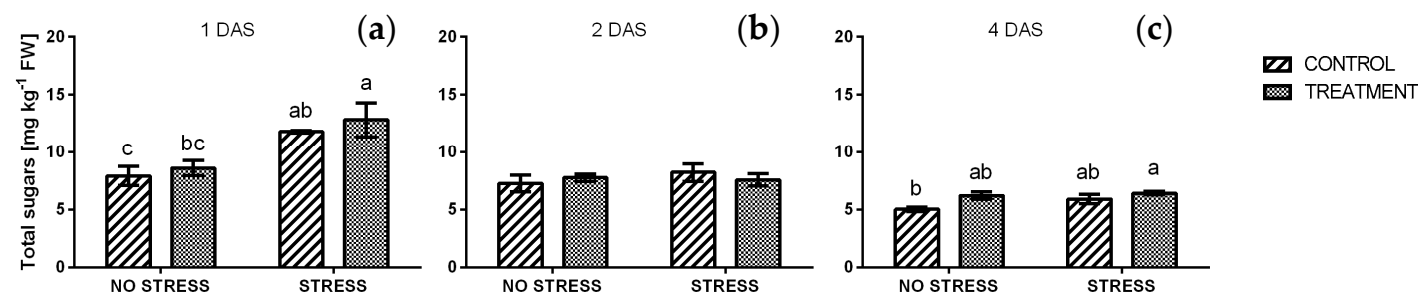

Figure 9. Total sugars concentration in rocket leaves treated with water (CONTROL) and with borage extract (TREATMENT) and subjected to salt stress (200 mM). Measures were taken after one day (a), two days $(\mathbf{b})$, and four days $(\mathbf{c})$ of stress. Values are means $\pm \mathrm{SE}(n=4)$. Data were subjected to two-way ANOVA. Different letters, where present, represent significant differences $(p<0.05)$.

\subsubsection{Lipid Peroxidation}

The level of lipid peroxidation in control plants grown under non-stressed conditions was around $12 \mathrm{nmol} \mathrm{g}^{-1} \mathrm{FW}$ at each time point, and a similar value was observed in response to borage treatment. After one day of stress (Figure 10a) a significant difference was found between plants treated with borage extract under stressed and non-stressed condition, while only a slight increase was observed in control plants. In particular, the highest level of lipid peroxidation was found in plants treated with borage extract and grown under salt stress $\left(20.7 \mathrm{nmol} \mathrm{g}^{-1} \mathrm{FW}\right)$. After two and four days, the level of lipid peroxidation in stressed samples slightly decreased to about $15 \mathrm{nmol} \mathrm{g}^{-1} \mathrm{FW}$. However, it remained significantly higher than non-stressed samples.

(a)

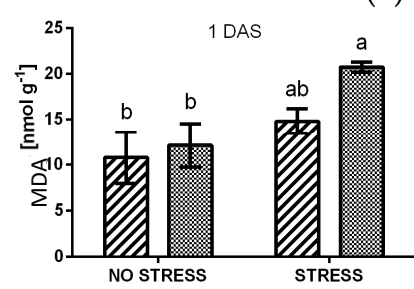

(b)

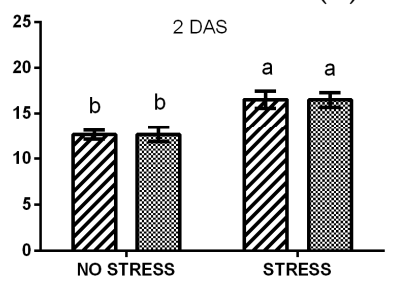

(c)

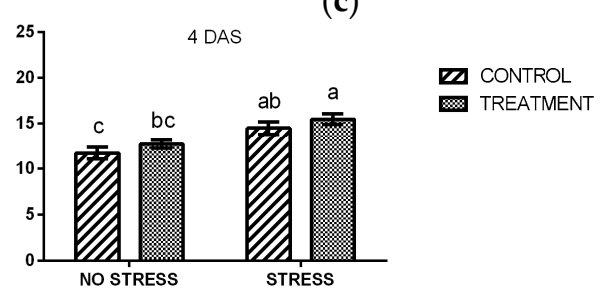

Figure 10. Concentration of malondialdehyde (MDA) in rocket leaves treated with water (CONTROL) and with borage extract (TREATMENT) and subjected to salt stress (200 $\mathrm{mM})$. Measures were taken one day $(\mathbf{a})$, two days, $(\mathbf{b})$ and four days $(\mathbf{c})$ of stress. Values are means $\pm \mathrm{SE}(n=4)$. Data were subjected to two-way ANOVA. Different letters, where present, represent significant differences $(p<0.05)$.

\subsubsection{Osmolytes}

The levels of osmolytes in rocket leaves (Figure 11) was not affected by the stress condition or by the borage treatment, in any of the time point analyzed. In particular, after one day of salt stress, all values averaged from 0.12 and $0.17 \mathrm{Osm} \mathrm{kg}^{-1} \mathrm{~g}^{-1}$. A slight increase appeared after two and four days (Figure 11b,c), however no significant difference was detected among the samples. 

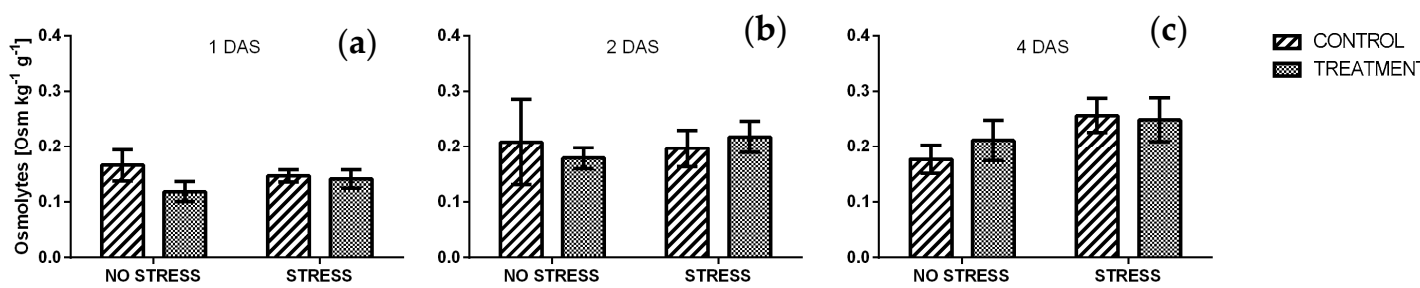

Figure 11. Osmolytes concentration in rocket leaves treated with water (CONTROL) and with borage extract (TREATMENT) and subjected to salt stress (200 mM). Measures were taken after one day (a), two days $(\mathbf{b})$, and four days $(\mathbf{c})$ of stress. Values are means \pm SE $(n=4)$. Data were subjected to two-way ANOVA. Different letters, where present, represent significant differences $(p<0.05)$.

\subsubsection{Abscisic Acid}

After one and four days (Table S2) a significant effect of the stress was found in the ANOVA. Initially, the average concentration of ABA in non-stressed samples was around $60 \mathrm{mg} \mathrm{g}^{-1}$ and no significant effect was detected after the application of the borage extract. The ABA contents in plants grown under stress conditions were significantly higher than in non-stressed ones, and averaged from 110.4 to $178.5 \mathrm{mg} \mathrm{g}^{-1}$. The highest level was reached in samples treated with borage extract and it was three times higher than in non-stressed samples (Figure 12a). After two days of stress (Figure 12b) the concentration of ABA did not change in almost all samples if compared with the previous time point. Moreover, the ANOVA showed a significant effect of treatment (Table S2). After four days the concentration of ABA in all samples decreased, and no significant difference was detected even if ABA levels in stressed samples were higher than non-stressed ones (Figure 12c).

(a)

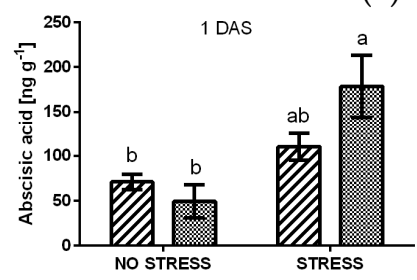

(b)

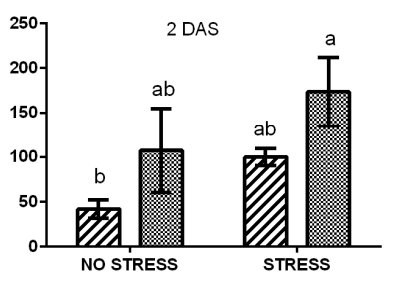

(c)

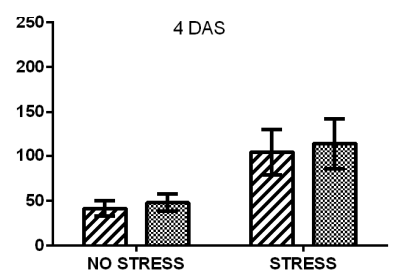

ש CONTROL TREATMENT

Figure 12. Abscisic acid concentration in rocket leaves treated with water (CONTROL) and with borage extract (TREATMENT) and subjected to salt stress (200 mM). Measures were taken one day (a), two days $(\mathbf{b})$ and four days (c) of the stress. Values are means \pm SE $(n=4)$. Data were subjected to two-way ANOVA. Different letters, where present, represent significant differences $(p<0.05)$.

\section{Discussion}

Diplotaxis tenuifolia can be considered as salt tolerant species due to its ability to maintain considerable growth rates under increasing salinity without any relevant variation to physiological parameters [11,27]. In the present study, rocket plants have been exposed to $200 \mathrm{mM} \mathrm{NaCl}$ for four days, just before the harvest, in order to evaluate the plant responses to salt shock with no acclimatization period. To better understand the nature of the different processes activated to cope the stress, a transcriptome analysis and the evaluation of different physiological and biochemical mechanisms in biostimulant-treated and not-treated rocket plants were analyzed.

At a molecular level, the transcriptional regulation depends on the interaction between transcription factors and a broad range of target genes involved in different stress responses pathways. TFs are involved in the primary stress responses, through the repression/activation of a set of genes associated with abiotic stress responses during the first few hours of stress exposure. For these reasons, 24 transcription factors belonging to different families and a stress-related gene (RD29A) were chosen and their expression within $24 \mathrm{~h}$ of salt stress was analyzed. Since TFs expression is dynamic and often transient, the measure at one single time point is not enough to understand their activity, thus their 
expression over time after 2, 4, 6, 9, and $24 \mathrm{~h}$ was evaluated. Most of the genes studied in this work showed a trend in their expression that might suggest a circadian control.

$R D 29 A$ is considered as a stress-response marker gene and has been studied in response to different abiotic stress treatments. In this experiment the DtRD29A expression constantly decreased under control conditions, both in untreated and treated plants. These values are consistent with those reported in another study, in which the gene was not expressed at significant levels during normal plant growing conditions [28]. As expected, DtRD29A transcripts increased under salt stress conditions, whereas its expression was particularly affected by the combination of $\mathrm{NaCl}$ and borage treatment. This result might suggest that rocket plants treated with borage extract were more sensitive to salt stress than the non-treated ones. Interestingly, Lee et al. [29] observed that RD29A expression pattern changed when exposed to single or combined (salt and ABA) treatments and the combination of the inputs led to unique dynamic behaviour that cannot be explained by the sum of the single responses. Li et al. [30] proposed an interaction between an ABRE binding protein (ABF3) and another transcription factor (NAC72) in the regulation of the expression of RD29A.

In our experiment, a rapid increase of DtNAC72 expression induced by salt exposure, similar to that reported by Tran et al. [31] in Arabidopsis thaliana exposed to $250 \mathrm{mM} \mathrm{NaCl}$ for $24 \mathrm{~h}$ was observed. Fujita et al. [32] observed a slower increase of the expression over time, probably due to the lower concentration of $\mathrm{NaCl}$ used in their experiment. Moreover, the same authors reported the existence of two different pathways for the NAC72 expression, one ABA-dependent in non-stressful condition, and the other ABA-independent under salt stress. It might explain why borage treatment induced the expression of DtNAC72 under salinity and not under normal growing conditions. In contrast, a gradual increase appeared in the expression of DtNAC019 in response to salt stress but in this case borage extract did not show any effect. Even if NAC019 and NAC72 are homologs, their response to salt and biostimulant treatment is quite different. Results obtained in the present study confirmed that both TFs are involved in stress response and may act in two different pathways.

Similar to $D t N A C 72$, the expression of $D t A B F 3$ was rapidly affected by salt stress. ABF3 plays an important role in $\mathrm{ABA}$ signaling both in normal and stressful conditions and it is induced by ABA and osmotic stress, as can be seen in reference [33].

MYB is a large family of transcription factors that are well-known to be involved in drought responses [34]. In this experiment the expression of two MYB TFs, DtMYB94 and DtMYB30 was examined. The expression of $D t M Y B 94$ constantly increased in response to salinity and was similar to those results reported for Arabidopsis [35]. At the same time, DtMYB30 expression showed a different pattern in response to salt and borage treatment. In general, its expression was lower in plants grown under stress. Recent studies reported that both MYB30 and MYB94 are involved in the activation of cuticular wax biosynthesis [35,36]. Moreover, MYB30 acts as a positive regulator of ABA signaling response [37], in the accumulation pattern of very-long-chain fatty acids such as waxes, phospholipids, and complex sphingolipids [38], and promoting the expression of a subset of brassinosteroids (BRs) target genes $[39,40]$. As mentioned above, an increase in lipid peroxidation was found in plant grown under salt stress and treated with borage extract. These finding may suggest that rocket plants reacted to salt stress through the accumulation of cuticular waxes and the production of new lipids molecules.

WRKY54 as well as MYB30 are involved in the BRs signaling pathway [41]. DtWRKY54 was expressed at low levels in control and untreated plants and was slightly induced by salt stress. A similar result was observed in Arabidopsis by Zhou et al. [42]. Moreover, the authors reported an increased tolerance to salt in transgenic soybean plants over-expressing WRKY54 gene. In rocket plants treated with borage, extracting the expression of DtWRKY 54 was induced under normal growing conditions, whereas it caused a general downregulation in plants exposed to salinity. Since WRKY54 co-operate with WRKY70 as negative regulators of the plant response to osmotic stress [43], so the lower expression levels observed in plants treated with borage and then exposed to salt stress might suggest a better tolerance to osmotic stress. 
Rocket plants grown under salt stress showed high levels in the expression of $D t H B 7$ and DtHB12. Both TFs belong to the HD ZIP family and are negative regulators of ABA signaling by acting as positive regulators of a protein phosphatase (PP2C) genes [44]. DtHB7 was more upregulated than DtHB12, confirming what was observed by Zimmermann et al. [45]. Moreover, plants overexpressing AtHB7 showed a higher chlorophyll content [46], and this might be linked to the high chlorophyll levels observed in rocket plants grown under salt stress.

ERF003, ERF107, and ERF39 are members of the ERF transcription factor subfamily and they are involved in abiotic stress responses through binding the ethylene-responsive element (ERE) [47]. Their expression has been reported to increase in response to high concentration of salt and to contribute to salt and drought tolerance [48-50]. In this study DtERF107 and DtERF39 expressions were induced in plants exposed to salt stress, in accordance with what is reported above. In contrast, the expression of DtERF003 rapidly increased in response to borage treatment but no changes appeared in plants exposed to salinity, suggesting that in rocket DtERF003 is not involved in salt stress response.

An overall upregulation of DtbHLH122 expression was found in rocket plants exposed to salt stress. BHLH122 has been reported to be a positive regulator of drought and osmotic stress signaling resistance and its expression is at least partly independent from ABA signaling [51]. The same authors reported that Arabidopsis plants overexpressing bHLH122 showed an increased resistance to water, salt and osmotic stresses. Moreover, bHLH122 was able to repress a gene involved in ABA catabolism, leading to the accumulation of ABA. These results might explain the increased content of ABA observed in rocket plants grown under salt stress and treated with borage extract.

Besides $b H L H 122$, the expression of other three TFs of bHLH family: BEE2, HBI1, and IBH1, all of which are involved in the brassinosteroids signaling pathway, was also analyzed. BEE2 and HBI1-like are induced by BRs and are repressed by ABA, while $I B H 1$ is reported to inhibit both $B E E 2$ and $H B I 1$. Moreover, plants overexpressing IBH1 showed a decreased stress response [52]. All TFs were generally expressed at very low levels in rocket plants regardless the growing condition. These results, together with the low expressions levels of DtMYB30 and DtWRKY54 and the up regulation of DtNAC72 (a negative regulator in the BRs signaling pathway) might suggest that for the specific condition tested in this study, stress responses in rocket plants are mediated more through ABA signaling pathways than through brassinosteroids signaling.

This is further confirmed by the increased concentration of ABA observed in rocket plants grown under salt stress. It is also known that an antagonistic interaction between ABA and BRs exists [53].

bZIP63 is a transcription factor involved in the processes regulating the circadian phase through the regulation of low-energy response. It is a target of a sugar-sensing kinase (SnRK1), a conserved gene usually activated during starvation [54,55]. In our experiment, we observed that DtbZIP63 expression was low in control plants and only a peak was observed after $24 \mathrm{~h}$. This time point corresponds to 8:00 am, and the accumulation of DtbZIP63 transcripts might be linked to a low concentration of sugars at night. Indeed, it has been reported that bZIP63 expression is usually repressed by sugars and ABA [56]. Interestingly, borage extract induced the expression of the gene under non-stressful conditions, even if the level of sugars and ABA in rocket leaves did not change. Moreover, bZIP63 is reported to function as a negative regulator of osmotic stress tolerance in Arabidopsis during seeds germination [57], thus the low expression detected in stressed plants might also confirm the mechanism of tolerance of rocket plants.

$\mathrm{RABC} 2 \mathrm{~B}$ is a protein involved in signal transduction and intracellular transport. In rocket plants $D t R A B C 2 B$ was generally expressed at low levels in both growing conditions, in contrast to those reported by Liu et al. [58], who observed an induction in response to salt stress in Arabidopsis. Borage treatment induced $D t R A B C 2 B$ expression, mostly after 2 and $4 \mathrm{~h}$ of stress exposition. However, to date there has been scarce information about the biological role and the regulation of these proteins in plants.

NAC92, NAC29, and NAC69 are involved in multiple abiotic stress responses. Their expression levels were generally low in leaves under non-stress conditions, as reported also by Xue et al. [59], and were induced by salt stress at different time points. 
The trend of expression of the unknown transcription factor was similar to those observed in $D t H B 7$ and DtDREB2A. Moreover, as well as DtBEE2, DtWRKY54, and DtERF107, a peak of transcript appeared after $9 \mathrm{~h}$.

An overall upregulation of the gene expression appeared in response to salt stress conditions. In general, the results obtained in the present experiment confirmed those reported in the transcriptome for most of the TFs analyzed. Novel findings emerged from the bZIP63, ERF107, DREB2A, and NAC92 expression. Moreover, the analysis of the gene expression over time allowed us to see the different trends in the TFs. For example, the expression levels of $\mathrm{C} 3 \mathrm{H} 49$ and $\mathrm{RABC} 2 \mathrm{~B}$ were higher in plants exposed to salt stress than with the unstressed controls after $24 \mathrm{~h}$, as reported by Cavaiuolo et al. [16]. However, the trend of their expression shows a constant decrease during time.

The content of chlorophyll and the chlorophyll fluorescence-related parameters did not significantly change in response to salt stress. These results are consistent with those reported in other studies, in which salt stress did not cause significant alteration in photosynthetic apparatus after few days of exposition to stressful conditions [60-62]. It is known that these parameters are considered as biochemical markers of salt tolerance, since chlorophyll levels and PSII efficiency usually decrease quickly in sensitive plants [63]. The content of chlorophyll in green leafy vegetable is also important because it defines the visual appearance of the product and influences the consumer choice [64]. The application of biostimulant products has been shown to increase the biosynthesis of chlorophyll in different vegetables $[65,66]$.

This experiment confirms that $D$. tenuifolia is a salt tolerant crop [11] due to its ability to counteract a sudden exposition to a high level of salinity, at least under our experimental conditions. At the same time, the short treatment time with the borage extract did not increase the chlorophyll content as well as the PSII efficiency in rocket plants grown under salt and non-salt conditions. In contrast, after one day of exposition to salt stress plants treated with borage extract showed a significant decrease of $\mathrm{Fv} / \mathrm{Fm}$ ratio. Since this value did not change in untreated plants in response to salt treatment and in plant treated with the borage extract grown in non-stressful condition, it may indicate that treatment induced the plant temporarily susceptible to salinity. The same effect observed in chlorophyll concentration was found also in carotenoids level and it makes sense because of their role as accessory light-harvesting pigments and protecting chlorophyll molecules. These results were compatible with those obtained by Bulgari et al. [25] after two applications of the same borage extract on rocket and lettuce plants grown under non-stressful conditions. No significant modification of chlorophyll and carotenoids content were also detected in Eruca sativa Mill. grown under salt stress, as reported by Barbieri et al. [67].

A moderate salinity has a positive effect increasing the concentration of phytochemicals, such as flavonoids, phenolic acids, and tannins [68-71]. These polyphenolic compounds play an important role in plant protection against reactive oxygen species (ROS), which are produced in plant tissues when physiological metabolism is impaired by various environmental stresses.

Besides their roles in plants, phenolic compounds exert an important function for human health due to their potential health benefits [72].

Several biostimulant products were reported to enhance the secondary metabolism and increase the synthesis of phytochemicals [73]. Borage extracts have shown to be effective in improving total phenols, flavonoids, and antioxidant capacity in lettuce plants [25]. This was not the case in the present study, as no significant changes were recorded, not in response to salt, not to treatment. A high variability in total phenols concentration was also observed by Hamilton et al. [74] within species and between trials. The different response obtained in our experiment compared to those reported by Bulgari et al. [25] by applying the same extract might be due to the number of applications or to genetic diversity of the treated plants. Moreover, the imposition of a significant level of salt might have "hidden" the effects of the borage extract observed in other experiments, probably related to the presence of molecules involved in the activation of signaling or exerting a hormone activity.

A significant increase of total sugars appeared in leaf tissues after one day of salt exposition, both in treated and non-treated plants. Afterwards, values declined to non-stress levels and remained 
stable until harvest (four days of salt stress). This trend may be related to the increased reduction of sugar concentrations observed. The accumulation of sugars has been reported in different plants species exposed to salinity $[75,76]$. Carbohydrates are products of photosynthesis and they are the building blocks and source of energy for plant growth. Besides these roles, sugars are involved in several processes related to plant stress responses, acting as signaling molecules, osmo-protectants, or antioxidants $[77,78]$. As reported by Shavrukov [13], when plants are suddenly exposed to a high level of salinity, they suffer osmotic shock and plasmolysis, regardless of their level of tolerance. Indeed, the only difference between a sensitive and a tolerant plant is the degree of damage and the time needed to restore physiological functions. In accordance with this, a significant increase in lipid peroxidation was detected in all stressed samples. The MDA content in unstressed plants treated and non-treated, was similar to the one observed by Ozdener et al. [79] in Eruca sativa Mill. suggesting that the application of borage extract did not cause any damage to cell membranes.

The accumulation of osmolytes is a typical response of plant exposed to salt stress condition in order to maintain the cell turgor pressure and stabilize proteins and other cell components against denaturing effects. Plants with an improved osmolyte biosynthesis generally showed an enhanced stress tolerance [80-82]. In this experiment no significant change in osmolytes accumulation was observed, and this result was unexpected.

Abscisic acid is a plant hormone with several roles in plant growth and development as well as in response to abiotic stresses. It has been suggested that some responses to osmotic stress could be modulated by ABA [83]. Frike et al. [84] reported that ABA accumulates in leaf tissues more than six times within $10 \mathrm{~min}$ in response to an environmental stress and within the first hour following the stress event, ABA has a growth-promoting function. A slight but non-significant increase in ABA levels was observed in plants grown under salt stress. This is in line to those results observed by $\mathrm{He}$ and Cramer [85]. They compared the ABA accumulation in two Brassica species and found that ABA concentration increased more in salt-sensitive species than in tolerant ones. Results obtained in the present experiment showed a slight increase of ABA content in treated plants, mostly in combination with the salinity. This may suggest that borage extract could have a slight positive effect on the production of ABA.

Rocket is a nitrate-accumulating vegetable and it is known that nitrate content in rocket leaves changes depending on the cultivation systems as well as on the environmental conditions, such as the light intensity, photoperiod, temperature, and abiotic stresses [86,87]. In humans, after ingestion, nitrates undergo different reactions that may lead to the formation of cancerogenic compounds like nitrosamines [88]. For this reason, the European Commission Regulation established limitations on the commercialization of several leafy vegetables (EU No 1258/2011). The maximum levels of nitrate for rocket salad are $7000 \mathrm{mg} \mathrm{NO}_{3}^{-} \mathrm{kg}^{-1}$ if harvested from October to March, and $6000 \mathrm{mg} \mathrm{NO}_{3}^{-} \mathrm{kg}^{-1}$ if harvested from April to September. In this experiment, reduced nitrate content was observed in plants exposed to salinity for one, two, and four days. These findings are consistent with those reported by Barbieri et al. [67] and Urrestarazu et al. [89] studies, in which a reduction of nitrate levels in rocket and lettuce salad was found after a high salinity treatment. Strategies to decrease the concentration of nitrate are important for the production of fresh vegetables and different biostimulant products showed a positive effect reducing the nitrate levels in several crop species $[66,90,91]$. However, nitrate contents were not affected by borage treatment, not under control or stress condition. This result was unexpected since, in contrast, Bulgari [92] observed an increase of NR activity in vivo and a substantial reduction of nitrate concentration in rocket plants treated with the same borage extract. This variability might be due to differences in the experimental plans (period of cultivation, number of treatments, timing of the application). 


\section{Materials and Methods}

\subsection{Plant Material, Stress Treatment and Experimental Plan}

The trial was carried out at the Faculty of Agricultural and Food Science of Milan in 2018. Rocket plants (Diplotaxis tenuifolia, L.; ISI Sementi S.P.A., Italy) were grown hydroponically into plastic tanks $(35 \times 25 \times 20 \mathrm{~cm})$ with $10 \mathrm{~L}$ of a modified Hoagland medium and the concentration of nutrient in the solution used was composed by $11.05 \mathrm{mM} \mathrm{N}, 1.4 \mathrm{mM} \mathrm{P}, 7 \mathrm{mM} \mathrm{K}, 2.19 \mathrm{mM} \mathrm{Ca}, 0.8 \mathrm{mM} \mathrm{Mg}$, and $1.8 \mathrm{mM} \mathrm{S}$, and Hoagland's concentration for micronutrients. Seeds of rocket were manually sown into polystyrene trays filled with an agri-perlite substrate on 20 February 2018. Cultivation took place in an experimental greenhouse under controlled conditions.

The experimental design was a combination of two factors: stress and treatment, each of them with two levels. Salt stress was imposed by transferring plants to a fresh nutrient solution containing $200 \mathrm{mM} \mathrm{NaCl}, 35$ days after sowing at $08.00 \mathrm{~h}$ (on March the $26^{\text {th }} 2018$ ). The nutrient solution of non-stressed plants was also changed with a fresh one.

Treatments consisted of $20 \mathrm{~mL}$ of water (control) and $20 \mathrm{~mL}$ of a borage extract. The plant extract used in this experiment had been previously prepared and tested by our research group, as described by Bulgari et al. [25]. The borage flower extract diluted $10 \mathrm{~mL} \mathrm{~L}^{-1}$ has been chosen as a treatment since the positive effects obtained in this study and in previous unpublished experiments. Treatments were applied on 25 March 2018, as foliar spray onto leaves until run-off $24 \mathrm{~h}$ before the beginning of the stress. For gene expression analyses, leaf tissues were collected after 2, 4, 6, 9, and $24 \mathrm{~h}$ of exposure to salt $(10.00 \mathrm{~h}, 12.00 \mathrm{~h}, 14.00 \mathrm{~h}, 17.00 \mathrm{~h}$, and $8.00 \mathrm{~h})$. Samples were shock frozen in liquid nitrogen before storage at $-80{ }^{\circ} \mathrm{C}$ and were then used for RNA isolation. For physiological analyses, leaf tissues were collected from four biological replicates after one, two, and four days of stress. Sampled material was stored at $-20^{\circ} \mathrm{C}$ prior to analyses.

\subsection{Total RNA Isolation and Analysis of Gene Expression}

Starting from the Diplotaxis tenuifolia L. RNAseq database (SRP study accession number SRP102718) created at the University of Milan [16], the sequences of 25 genes were identified in order to be used as molecular markers for salt stress (Table S3). The sequences were selected among those showing significant changes in their expression (RPKM) in response to $24 \mathrm{~h}$ of exposure to salt stress conditions. Annotation for all sequences was verified by using NCBI BLAST database and their involvement in salt stress responses mechanisms has been confirmed through the literature review. Among them, 23 TFs have been identified and 1 did not show any correspondence to known gene sequences, thus it has been reported as unknown 2. Specific primers (Table S4) for all selected sequences (24 transcription factors and $R D 29 A$ ) were designed using the program Primer-Blast available at the National Center for Biotechnology Information website (https://www.ncbi.nlm.nih.gov/tools/primer-blast/).

Frozen leaves of rocket plants were thoroughly ground with liquid $\mathrm{N}$ using cold mortar and pestle. Approximately $100 \mathrm{mg}$ were transferred to a cryotube and stored at $-80^{\circ} \mathrm{C}$. Total RNA was isolated using the Spectrum Plant Total RNA Kit with on-column DNase-treatment (Sigma-Aldrich, Italy) following the steps of protocol A with a slight modification.

The concentration and the purity of RNA were assessed by measuring the absorbance at $230 \mathrm{~nm}$, $260 \mathrm{~nm}$, and $280 \mathrm{~nm}$ using a NanoDrop N-1000 spectrophotometer (NanoDrop technologies). A ratio of absorbance at 260 and $280 \approx 2.0$ is generally accepted as pure for RNA and expected 260/230 values are commonly in the range of 2.0-2.2, usually higher than the respective 260/280 value.

Three $\mu \mathrm{g}$ of RNA were reversely transcribed to cDNA using the SuperScript III cDNA Synthesis Kit according to the manufacturer's instructions (Invitrogen, Italy).

The SYBR ${ }^{\circledR}$ Green PCR Master Mix (Applied Biosystems) was used for the quantitative RT-PCR analysis. The reaction mix was prepared by adding $10 \mu \mathrm{L}$ of SYBR Green, $0.4 \mu \mathrm{L}$ of forward and reverse primers, $2 \mu \mathrm{L}$ of cDNA diluted 1:20, and 7.2 $\mu \mathrm{L}$ of RNase free water. The total volume for each PCR 
reaction was $20 \mu \mathrm{L}$. Analysis was performed using the ABI7300 (Applied Biosystem) thermocycler and PCR program and reactions were run in triplicate from two biological replicates.

The expression levels were analyzed with the $\mathrm{AB}$ software program and results were calculated using the $2^{-\Delta \Delta c t}$ method described by Livak and Schmittgen [93]. According to this method, the data are presented as fold change in gene expression normalized to a housekeeping gene and relative to a calibrator. The Elongation factor 1 alpha $(\mathrm{EF} 1 \alpha)$ was used as reference gene (housekeeping) since the ct values showed high stability in the same species grown under similar experimental conditions [61], whereas the non-stressed and non-treated sample after $2 \mathrm{~h}$ was chosen as an internal calibrator.

\subsection{Physiological Analyses}

\subsubsection{Chlorophyll}

Leaves chlorophyll content was estimated in vivo using a chlorophyll content meter (CL-01 Chlorophyll Content Meter, Hansatech Instruments). The results were expressed as a chlorophyll index (relative units).

\subsubsection{Chlorophyll a Fluorescence}

Chlorophyll $a$ fluorescence was measured in vivo using a hand-portable fluorometer (Handy-PEA, Hansatech Instruments). Before all measurement leaves were dark-adapted with the leaf clips for 30-40 $\mathrm{min}$. then were exposed to a saturating light $\left(3000 \mu \mathrm{mol} \mathrm{m}^{-2} \mathrm{~s}^{-1}\right)$ provided by an array of three high-intensity light-emitting diodes for $1 \mathrm{~s}$. Information about the structural and functional status of photosynthetic apparatus was provided by the parameters measured, such as the maximum quantum of photosystem II (Fv/Fm) or the performance index (PI) derived from the JIP test calculation [94].

\subsubsection{Total Chlorophylls and Carotenoids}

Chlorophylls and carotenoids were extracted from rocket leaves using $5 \mathrm{~mL}$ of $99.9 \%(\mathrm{v} / \mathrm{v})$ methanol. Leaf disc samples $(30 \mathrm{mg}$ ), obtained with a $5 \mathrm{~mm}$ diameter cork borer were kept in a dark room for $24 \mathrm{~h}$ at $4{ }^{\circ} \mathrm{C}$. After that absorbance reading were measured at 665.2 and $652.4 \mathrm{~nm}$ for chlorophylls and $470 \mathrm{~nm}$ for total carotenoids with a spectrophotometer. Pigments levels were calculated by Lichtenthaler's formula and expressed on a fresh weight basis [95].

\subsubsection{Phenolic Index and Total Anthocyanin}

Phenolic index and total anthocyanin were determined from leaf disc samples (30 mg), obtained with a $5 \mathrm{~mm}$ diameter cork borer. Leaf samples were transferred to a tube containing $3 \mathrm{~mL}$ of methanol acidified with hydrochloric acid $(1 \%)$ and were kept in dark room for $24 \mathrm{~h}$ at $4{ }^{\circ} \mathrm{C}$. Absorbance readings were measured at $320 \mathrm{~nm}$ for total phenols, and at $535 \mathrm{~nm}$ for anthocyanin with a spectrophotometer. Phenolic index was expressed as Abs320 $\mathrm{nm} \mathrm{g}^{-1} \mathrm{FW}$ [96]. Anthocyanins concentration was expressed in cyaniding-3-glucoside equivalents using a molar extinction coefficient $(\varepsilon)$ of $29,600 \mathrm{~L} \mathrm{M}^{-1} \mathrm{~cm}^{-1}$ [97].

\subsubsection{Nitrate}

Nitrate concentration was determined by the method of Cataldo et al. [98]. Fresh leaf tissue was homogenized in distilled water ( $1 \mathrm{~g}$ fresh tissue per $4 \mathrm{~mL}$ distilled water). The homogenate was centrifuged at $4000 \mathrm{rpm}$ for $15 \mathrm{~min}$ at RT (ALC centrifuge-model PK130R) and the recovered supernatant was used for the colorimetric analysis. Twenty microliters of the extract were added to $80 \mathrm{~mL}$ of $5 \%(\mathrm{w} / \mathrm{v})$ salicylic acid in concentrated $\mathrm{H}_{2} \mathrm{SO}_{4}\left(\mathrm{SA}-\mathrm{H}_{2} \mathrm{SO}_{4}\right)$. Afterwards, $3 \mathrm{~mL}$ of $1.5 \mathrm{~N}$ $\mathrm{NaOH}$ were added. The samples were cooled to RT and absorbance at $410 \mathrm{~nm}$ was measured with a spectrophotometer. Nitrate content was calculated referring to a $\mathrm{KNO}_{3}$ standard calibration curve. Nitrate concentration was expressed as $\mathrm{mg}$ of $\mathrm{NO}_{3}-\mathrm{N}$ per $\mathrm{kg}$ of fresh weight. 


\subsubsection{Reducing and Total Sugars}

Reducing sugars were measured using the dinitrosalicylic (DNS) acid method. This colorimetric technique consists of a redox reaction between the 3,5-dinitrosalicyclic acid and the reducing sugars present in the sample [99]. Approximately $1 \mathrm{~g}$ of leaf tissue was homogenized in a mortar with $3 \mathrm{~mL}$ of water. The mixture was centrifuged at $4000 \mathrm{rpm}$ for $15 \mathrm{~min}$ at RT. DNS assay was performed by mixing $0.2 \mathrm{~mL}$ of supernatant with $0.2 \mathrm{~mL}$ of DNS and incubated in a water bath at $100{ }^{\circ} \mathrm{C}$ for $5 \mathrm{~min}$, then $1.5 \mathrm{~mL}$ of water was added to samples. After cooling at room temperature, the optical density was determined spectrophotometrically at $530 \mathrm{~nm}$, using a glucose standard curve.

The total sugars were determined on the same extract using the anthrone method with slight modifications [100]. The anthrone reagent $(10.3 \mathrm{mM})$ was prepared dissolving anthrone in $95 \% \mathrm{H}_{2} \mathrm{SO}_{4}$. The reagent was left to stand for 30-40 min before use, $0.5 \mathrm{~mL}$ extract was placed on top of $2.5 \mathrm{~mL}$ of anthrone reagent incubated in ice for $5 \mathrm{~min}$ and then vortexed vigorously. The tubes were heated to $95^{\circ} \mathrm{C}$ for $10 \mathrm{~min}$ and left to cool in ice. Readings were performed at $620 \mathrm{~nm}$. Calibration curve was carried out using a glucose standard solution.

\subsubsection{Lipid Peroxidation}

Lipid peroxidation was determined by measuring thiobarbituric acid reactive substances (TBARS) in accordance with the method described by Heath and Parker [101]. Approximately $1 \mathrm{~g}$ of leaf tissue was homogenized in a mortar with $3 \mathrm{~mL}$ of $0.1 \%(\mathrm{w} / \mathrm{v})$ trichloroacetic acid (TCA). The mixture was centrifuged at $4500 \mathrm{rpm}$ for $10 \mathrm{~min}$ at room temperature. TBARS assay was performed by mixing $1 \mathrm{~mL}$ of supernatant with $4 \mathrm{~mL}$ of $20 \%(\mathrm{w} / \mathrm{v}) \mathrm{TCA}, 25 \mu \mathrm{L}$ of $0.5 \%$ thiobarbituric acid (TBA) and incubated in a water bath at $95^{\circ} \mathrm{C}$ for $30 \mathrm{~min}$. After being cooled on ice, the tubes were centrifugated at $4000 \mathrm{rpm}$ for $10 \mathrm{~min}$ and the optical density was determined spectrophotometrically at 532 and $600 \mathrm{~nm}$. Absorbance at $600 \mathrm{~nm}$ was subtracted from the absorbance at $532 \mathrm{~nm}$ (as an index of non-specific turbidity) and the concentration of TBARS was calculated using the Lambert-Beer law with an extinction coefficient $\varepsilon \mathrm{M}=155 \mathrm{mM}^{-1} \mathrm{~cm}^{-1}$ and expressed as malondialdehyde (MDA) equivalents ( $\mathrm{nmol} \mathrm{g}{ }^{-1}$ ) in line with Du and Bramlage [102].

\subsubsection{Osmolytes}

Fresh leaf tissue was homogenized in distilled water ( 1 fresh tissue per $4 \mathrm{~mL}$ distilled water). The homogenate was centrifuged at $4000 \mathrm{rpm}$ for $15 \mathrm{~min}$ at RT and the recovered supernatant was analyzed. Its osmolarity was determined using an automatic freezing point depression osmometer (Digital Osmometer, Roebling, Berlin, Germany) calibrated with sodium chloride solutions.

\subsubsection{Abscisic Acid}

Approximately $1 \mathrm{~g}$ of leaf tissue was homogenized in a mortar with $3 \mathrm{~mL}$ of water, the mixture was centrifuged at $4000 \mathrm{rpm}$ for $15 \mathrm{~min}$ at RT and the supernatant was collected and then stored at $-80^{\circ} \mathrm{C}$ until analysis. The abscisic acid (ABA) concentration was determined by an indirect enzyme linked immuno-sorbent assay based on the use of DBPA1 monoclonal antibody, raised against $\mathrm{S}(+)$-ABA following the procedures of Trivellini et al. [103].

\subsection{Statistical Analyses}

Data obtained from physiological analyses were subjected to a two-way ANOVA, whereas data related to gene expression analysis were subjected to a three-way ANOVA. Differences among means were determined using the Tuckey post-test $(p<0.05)$. Statistics were performed using GraphPad Prism version 6 or 8 for Windows (GraphPad Software, La Jolla California USA, www.graphpad.com). Additional information is reported in each figure's legend. 


\section{Conclusions}

In conclusion, results obtained in this work allowed understanding of some of the mechanisms used by Diplotaxis tenuifolia L. to cope with a significant level of salt stress, in response to a foliar treatment with a borage extracts, and the combination of both factors. Moreover, it also allowed us to study the pattern of expression of several transcription factors belonging to different families involved in salt stress responses over time. Transcription factors were found to be involved in the regulation of several pathways such as the biosynthesis of cuticular waxes, phospholipids and brassinosteroids, the sugar metabolism, and the intracellular transport. The results obtained in this work about the response of rocket to the borage extract application as a biostimulant highlighted the difficulty of determining the exact mode of action of these products.

Supplementary Materials: The following are available online at http://www.mdpi.com/2223-7747/9/1/20/s1, Figure S1: Changes in the expression of DtRD29A in rocket leaves treated with water (CONTROL) and with borage extract (TREATMENT) and subjected to salt stress $(200 \mathrm{mM})$. Measures were taken 2, 4, 6, 9, $24 \mathrm{~h}$ after the initial exposure to salt stress, Figure S2: Changes in the expression of DtDREB2A (a), DtERF107 (b), DtERF003 (c), DtERF039 (d) in rocket leaves treated with water (CONTROL) and with borage extract (TREATMENT) and subjected to salt stress $(200 \mathrm{mM})$. Measures were taken 2, 4, 6, 9, $24 \mathrm{~h}$ after the initial exposure to salt stress, Figure S3: Changes in the expression of DtbHLH122 (a), DtBEE2 (b), DtHBI1-like (c) and DtIBH1-like (d) in rocket leaves treated with water (CONTROL) and with borage extract (TREATMENT) and subjected to salt stress $(200 \mathrm{mM})$. Measures were taken 2, 4, 6, 9, $24 \mathrm{~h}$ after the initial exposure to salt stress, Figure S4: Changes in the expression of DtMYB30 (a) and DtMYB94 (b) in rocket leaves treated with water (CONTROL) and with borage extract (TREATMENT) and subjected to salt stress (200 mM). Measures were taken 2, 4, 6, 9, $24 \mathrm{~h}$ after the initial exposure to salt stress, Figure S5: Changes in the expression of DtNAC29 (a), DtNAC72 (b), DtANAC69 (c), DtNAC92 (d) and DtNAC019 (e) in rocket leaves treated with water (CONTROL) and with borage extract (TREATMENT) and subjected to salt stress $(200 \mathrm{mM})$. Measures were taken 2, 4, 6, 9, $24 \mathrm{~h}$ after the initial exposure to salt stress, Figure S6: Changes in the expression of DtC3H49 (a) and DtZAT12-like (b) in rocket leaves treated with water (CONTROL) and with borage extract (TREATMENT) and subjected to salt stress (200 mM). Measures were taken 2, 4, 6, 9, $24 \mathrm{~h}$ after the initial exposure to salt stress, Figure S7: Changes in the expression of DtABF3 (a) and DtbZIP63 (b) in rocket leaves treated with water (CONTROL) and with borage extract (TREATMENT) and subjected to salt stress $(200 \mathrm{mM})$. Measures were taken 2, 4, 6, 9, $24 \mathrm{~h}$ after the initial exposure to salt stress, Figure S8: Changes in the expression of DtWRKY54 in rocket leaves treated with water (CONTROL) and with borage extract (TREATMENT) and subjected to salt stress $(200 \mathrm{mM})$. Measures were taken 2, 4, 6, 9, $24 \mathrm{~h}$ after the initial exposure to salt stress, Figure S9. Changes in the expression of DtHB12 (a) and DtHB7 (b) in rocket leaves treated with water (CONTROL) and with borage extract (TREATMENT) and subjected to salt stress $(200 \mathrm{mM})$. Measures were taken 2, 4, 6, 9, $24 \mathrm{~h}$ after the initial exposure to salt stress, Figure S10: Changes in the expression of DtRABC2B in rocket leaves treated with water $(C O N T R O L)$ and with borage extract (TREATMENT) and subjected to salt stress (200 mM). Measures were taken 2, 4, 6, 9, $24 \mathrm{~h}$ after the initial exposure to salt stress, Figure S11: Changes in the expression of an unknown transcription factors named Unknown2 in rocket leaves treated with water (CONTROL) and with borage extract (TREATMENT) and subjected to salt stress (200 $\mathrm{mM})$. Measures were taken $2,4,6,9,24 \mathrm{~h}$ after the initial exposure to salt stress, Table S1: Statistical results of gene expression analyses on rocket plants treated with borage extract and grown under salt stress condition. "S" means STRESS, "T" means TREATMENT, " $\mathrm{t}$ " means TIME, " $\mathrm{x}$ " means the INTERACTION between factors, Table S2: Results of ANOVA of physiological analyses on rocket plants treated with borage extract and grown under salt stress condition after 1,2 and 4 days from the sawing (DAS). " $\mathrm{S}$ " means STRESS, " $\mathrm{T}$ " means TREATMENT, " $\mathrm{x}$ " means the INTERACTION between factors, Table S3: Transcription factors selected from the Diplotaxis tenuifolia RNAseq EST database, grouped by family and divided according to the results obtained by Cavaiuolo et al., (2017), Table S4: Accession number, primers sequences and melting temperature $(\mathrm{Tm})$ for qRT-PCR analysis.

Author Contributions: Conceptualization, A.F., G.F. and G.C.; formal analysis, G.F., G.C. and A.T.; data curation, G.F.; writing—original draft preparation, G.F.; writing — review and editing, G.F., G.C., A.T.; supervision, A.F. All authors have read and agreed to the published version of the manuscript.

Funding: This research received no external funding.

Conflicts of Interest: The authors declare no conflict of interest.

\section{References}

1. Ivushkin, K.; Bartholomeus, H.; Bregt, A.K.; Pulatov, A.; Kempen, B.; de Sousa, L. Global mapping of soil salinity change. Remote Sens. Environ. 2019, 231. [CrossRef]

2. Shrivastava, P.; Kumar, R. Soil salinity: A serious environmental issue and plant growth promoting bacteria as one of the tools for its alleviation. Saudi J. Biol. Sci. 2015, 22, 123-131. [CrossRef] [PubMed]

3. Munns, R. Genes and salt tolerance: Bringing them together. New Phytol. 2005, 167, 645-663. [CrossRef] 
4. Hniličková, H.; Hnilička, F.; Martinková, J.; Kraus, K. Effects of salt stress on water status, photosynthesis and chlorophyll fluorescence of rocket. Plant Soil Environ. 2017, 63, 362-367.

5. Najar, R.; Aydi, S.; Sassi-Aydi, S.; Zarai, A.; Abdelly, C. Effect of salt stress on photosynthesis and chlorophyll fluorescence in Medicago truncatula. Plant Biosyst. Int. J. Deal. Asp. Plant Biol. 2019, 153, 88-97. [CrossRef]

6. Jacoby, R.P.; Taylor, N.L.; Millar, A.H. The role of mitochondrial respiration in salinity tolerance. Trends Plant Sci. 2011, 16, 614-623. [CrossRef]

7. Peleg, Z.; Blumwald, E. Hormone balance and abiotic stress tolerance in crop plants. Curr. Opin. Plant Biol. 2011, 14, 290-295. [CrossRef]

8. Cheeseman, J.M. The evolution of halophytes, glycophytes and crops, and its implications for food security under saline conditions. New Phytol. 2015, 206, 557-570. [CrossRef]

9. Flowers, T.J.; Troke, P.F.; Yeo, A.R. The Mechanism of Salt Tolerance in Halophytes. Annu. Rev. Plant Physiol. 1977, 28, 89-121. [CrossRef]

10. Glenn, E.P.; Brown, J.J.; Blumwald, E. Salt tolerance and crop potential of halophytes. Crit. Rev. Plant Sci. 1999, 18, 227-255. [CrossRef]

11. de Vos, A.C.; Broekman, R.; de Almeida Guerra, C.C.; van Rijsselberghe, M.; Rozema, J. Developing and testing new halophyte crops: A case study of salt tolerance of two species of the Brassicaceae, Diplotaxis tenuifolia and Cochlearia officinalis. Environ. Exp. Bot. 2013, 92, 154-164. [CrossRef]

12. Munns, R.; Termaat, A. Whole-plant responses to salinity. Aust. J. Plant Physiol. 1986, 13, 143-160. [CrossRef]

13. Shavrukov, Y. Salt stress or salt shock: Which genes are we studying? J. Exp. Bot. 2013, 64, 119-127. [CrossRef] [PubMed]

14. Parida, A.K.; Das, A.B. Salt tolerance and salinity effects on plants: A review. Ecotoxicol. Environ. Saf. 2005, 60, 324-349. [CrossRef] [PubMed]

15. Ciarmiello, L.F.; Woodrow, P.; Piccirillo, P.; De Luca, A.; Carillo, P. Transcription Factors and Environmental Stresses in Plants. Emerg. Technol. Manag. Crop Stress Toler. 2014, 1, 57-78.

16. Cavaiuolo, M.; Cocetta, G.; Spadafora, N.D.; Müller, C.T.; Rogers, H.J.; Ferrante, A. Gene expression analysis of rocket salad under pre-harvest and postharvest stresses: A transcriptomic resource for Diplotaxis tenuifolia. PLoS ONE 2017, 12, e0178119. [CrossRef] [PubMed]

17. Hoang, X.L.T.; Nhi, D.N.H.; Thu, N.B.A.; Thao, N.P.; Tran, L.-S.P. Transcription Factors and Their Roles in Signal Transduction in Plants under Abiotic Stresses. Curr. Genom. 2017, 18, 483-497. [CrossRef]

18. Khan, S.-A.; Li, M.-Z.; Wang, S.-M.; Yin, H.-J. Revisiting the Role of Plant Transcription Factors in the Battle against Abiotic Stress. Int. J. Mol. Sci. 2018, 19, 1634. [CrossRef]

19. Kumar, J.; Singh, S.; Singh, M.; Srivastava, P.K.; Mishra, R.K.; Singh, V.P.; Prasad, S.M. Transcriptional regulation of salinity stress in plants: A short review. Plant Gene 2017, 11, 160-169. [CrossRef]

20. Singh, K. Transcription factors in plant defense and stress responses. Curr. Opin. Plant Biol. 2002, 5, 430-436. [CrossRef]

21. Kimotho, R.N.; Baillo, E.H.; Zhang, Z. Transcription factors involved in abiotic stress responses in Maize (Zea mays L.) and their roles in enhanced productivity in the post genomics era. Peer J. 2019, 7, e7211. [CrossRef] [PubMed]

22. Trevisan, S.; Manoli, A.; Ravazzolo, L.; Franceschi, C.; Quaggiotti, S. mRNA-Sequencing Analysis Reveals Transcriptional Changes in Root of Maize Seedlings Treated with Two Increasing Concentrations of a New Biostimulant. J. Agric. Food Chem. 2017, 65, 9956-9969. [CrossRef] [PubMed]

23. Khan, M.S.; Pandey, M.K.; Hemalatha, S. Comparative Studies on the Role of Organic Biostimulant in Resistant and Susceptible Cultivars of Rice Grown under Saline Stress-Organic Biostimulant Alleviate Saline Stress in Tolerant and Susceptible Cultivars of Rice. J. Crop Sci. Biotechnol. 2018, 21, 459-467. [CrossRef]

24. Santi, C.; Zamboni, A.; Varanini, Z.; Pandolfini, T. Growth Stimulatory Effects and Genome-Wide Transcriptional Changes Produced by Protein Hydrolysates in Maize Seedlings. Front. Plant Sci. 2017, 8, 433. [CrossRef] [PubMed]

25. Bulgari, R.; Morgutti, S.; Cocetta, G.; Negrini, N.; Farris, S.; Calcante, A.; Spinardi, A.; Ferrari, E.; Mignani, I.; Oberti, R.; et al. Evaluation of Borage Extracts As Potential Biostimulant Using a Phenomic, Agronomic, Physiological, and Biochemical Approach. Front. Plant Sci. 2017, 8, 1-16. [CrossRef] [PubMed]

26. Maxwell, K.; Johnson, G.N. Chlorophyll fluorescence-A practical guide. J. Exp. Bot. 2000, 51, 659-668. [CrossRef] 
27. Caruso, G.; Parrella, G.; Giorgini, M.; Nicoletti, R. Crop Systems, Quality and Protection of Diplotaxis tenuifolia. Agriculture 2018, 8, 55. [CrossRef]

28. Msanne, J.; Lin, J.; Stone, J.M.; Awada, T. Characterization of abiotic stress-responsive Arabidopsis thaliana RD29A and RD29B genes and evaluation of transgenes. Planta 2011, 234, 97-107. [CrossRef]

29. Lee, S.Y.; Boon, N.J.; Webb, A.A.R.; Tanaka, R.J. Synergistic activation of RD29A via integration of salinity stress and abscisic acid in arabidopsis thaliana. Plant Cell Physiol. 2016, 57, 2147-2160. [CrossRef]

30. Li, X.; Li, X.; Li, M.; Yan, Y.; Liu, X.; Li, L. Dual Function of NAC072 in ABF3-Mediated ABA-Responsive Gene Regulation in Arabidopsis. Front. Plant Sci. 2016, 7, 1-9. [CrossRef]

31. Tran, L.-S.P.; Nakashima, K.; Sakuma, Y.; Simpson, S.D.; Fujita, Y.; Maruyama, K.; Fujita, M.; Seki, M.; Shinozaki, K.; Yamaguchi-Shinozaki, K. Isolation and Functional Analysis of Arabidopsis Stress-Inducible NAC Transcription Factors That Bind to a Drought-Responsive cis -Element in the early responsive to dehydration stress 1 Promoter. Plant Cell 2004, 16, 2481-2498. [CrossRef] [PubMed]

32. Fujita, M.; Fujita, Y.; Maruyama, K.; Seki, M.; Hiratsu, K.; Ohme-Takagi, M.; Tran, L.S.P.; Yamaguchi-Shinozaki, K.; Shinozaki, K. A dehydration-induced NAC protein, RD26, is involved in a novel ABA-dependent stress-signaling pathway. Plant J. 2004, 39, 863-876. [CrossRef] [PubMed]

33. Bogamuwa, S.P.; Jang, J.C. Tandem CCCH zinc finger proteins in plant growth, development and stress response. Plant Cell Physiol. 2014, 55, 1367-1375. [CrossRef] [PubMed]

34. Benny, J.; Pisciotta, A.; Caruso, T.; Martinelli, F. Identification of key genes and its chromosome regions linked to drought responses in leaves across different crops through meta-analysis of RNA-Seq data. BMC Plant Biol. 2019, 19, 194. [CrossRef] [PubMed]

35. Lee, S.B.; Suh, M.C. Cuticular Wax Biosynthesis is Up-Regulated by the MYB94 Transcription Factor in Arabidopsis. Plant Cell Physiol. 2015, 56, 48-60. [CrossRef]

36. Lee, S.B.; Kim, H.U.; Suh, M.C. MYB94 and MYB96 Additively Activate Cuticular Wax Biosynthesis in Arabidopsis. Plant Cell Physiol. 2016, 57, 2300-2311. [CrossRef]

37. Zheng, Y.; Schumaker, K.S.; Guo, Y. Sumoylation of transcription factor MYB30 by the small ubiquitin-like modifier E3 ligase SIZ1 mediates abscisic acid response in Arabidopsis thaliana. Proc. Natl. Acad. Sci. USA 2012, 109, 12822-12827. [CrossRef]

38. Raffaele, S.; Vailleau, F.; Léger, A.; Joubès, J.; Miersch, O.; Huard, C.; Blée, E.; Mongrand, S.; Domergue, F.; Roby, D. A MYB Transcription Factor Regulates Very-Long-Chain Fatty Acid Biosynthesis for Activation of the Hypersensitive Cell Death Response in Arabidopsis. Plant Cell 2008, 20, 752-767. [CrossRef]

39. Li, L.; Yu, X.; Thompson, A.; Guo, M.; Yoshida, S.; Asami, T.; Chory, J.; Yin, Y. Arabidopsis MYB30 is a direct target of BES1 and cooperates with BES1 to regulate brassinosteroid-induced gene expression. Plant J. 2009, 58, 275-286. [CrossRef]

40. Ashraf, M.; Akram, N.A.; Arteca, R.N.; Foolad, M.R. The Physiological, Biochemical and Molecular Roles of Brassinosteroids and Salicylic Acid in Plant Processes and Salt Tolerance. Crit. Rev. Plant Sci. 2010, 29, 162-190. [CrossRef]

41. Chen, J.; Nolan, T.; Ye, H.; Zhang, M.; Tong, H.; Xin, P.; Chu, J.; Chu, C.; Li, Z.; Yin, Y. Arabidopsis WRKY46, WRKY54 and WRKY70 Transcription Factors Are Involved in Brassinosteroid-Regulated Plant Growth and Drought Response. Plant Cell 2017, 29, 1425-1439. [CrossRef] [PubMed]

42. Zhou, Q.-Y.; Tian, A.-G.; Zou, H.-F.; Xie, Z.-M.; Lei, G.; Huang, J.; Wang, C.-M.; Wang, H.-W.; Zhang, J.-S.; Chen, S.-Y. Soybean WRKY-type transcription factor genes, GmWRKY13, GmWRKY21, and GmWRKY54, confer differential tolerance to abiotic stresses in transgenic Arabidopsis plants. Plant Biotechnol. J. 2008, 6, 486-503. [CrossRef] [PubMed]

43. Li, J.; Besseau, S.; Törönen, P.; Sipari, N.; Kollist, H.; Holm, L.; Palva, E.T. Defense-related transcription factors WRKY70 and WRKY54 modulate osmotic stress tolerance by regulating stomatal aperture in Arabidopsis. New Phytol. 2013, 200, 457-472. [CrossRef] [PubMed]

44. Valdés, A.E.; Övernäs, E.; Johansson, H.; Rada-Iglesias, A.; Engström, P. The homeodomain-leucine zipper (HD-Zip) class I transcription factors ATHB7 and ATHB12 modulate abscisic acid signalling by regulating protein phosphatase 2C and abscisic acid receptor gene activities. Plant Mol. Biol. 2012, 80, 405-418. [CrossRef] [PubMed]

45. Zimmermann, P.; Hirsch-hoffmann, M.; Hennig, L.; Gruissem, W. GENEVESTIGATOR. Arabidopsis Microarray Database and Analysis Toolbox. Plant Physiol. 2004, 136, 2621-2632. [CrossRef] [PubMed] 
46. Ré, D.A.; Capella, M.; Bonaventure, G.; Chan, R.L. Arabidopsis AtHB7 and AtHB12 evolved divergently to fine tune processes associated with growth and responses to water stress. BMC Plant Biol. 2014, 14, 150. [CrossRef]

47. Mizoi, J.; Shinozaki, K.; Yamaguchi-Shinozaki, K. AP2/ERF family transcription factors in plant abiotic stress responses. Biochim. Biophys. Acta-Gene Regul. Mech. 2012, 1819, 86-96. [CrossRef]

48. Sun, Z.-M.; Zhou, M.-L.; Wang, D.; Tang, Y.-X.; Lin, M.; Wu, Y.-M. Overexpression of the Lotus corniculatus Soloist Gene LcAP2/ERF107 Enhances Tolerance to Salt Stress. Prot. Pept. Lett. 2016, 23, 442-449. [CrossRef]

49. Rong, W.; Qi, L.; Wang, A.; Ye, X.; Du, L.; Liang, H.; Xin, Z.; Zhang, Z. The ERF transcription factor TaERF3 promotes tolerance to salt and drought stresses in wheat. Plant Biotechnol. J. 2014, 12, 468-479. [CrossRef]

50. Song, C.P.; Galbraith, D.W. AtSAP18, an orthologue of human SAP18, is involved in the regulation of salt stress and mediates transcriptional repression in Arabidopsis. Plant Mol. Biol. 2006, 60, 241-257. [CrossRef]

51. Liu, W.; Tai, H.; Li, S.; Gao, W.; Zhao, M.; Xie, C.; Li, W.X. bHLH122 is important for drought and osmotic stress resistance in Arabidopsis and in the repression of ABA catabolism. New Phytol. 2014, 201, 1192-1204. [CrossRef] [PubMed]

52. Zhang, C.; Bai, M.Y.; Chong, K. Brassinosteroid-mediated regulation of agronomic traits in rice. Plant Cell Rep. 2014, 33, 683-696. [CrossRef] [PubMed]

53. Clouse, S.D. Previews Brassinosteroid/Abscisic Acid Antagonism in Balancing Growth and Stress. Dev. Cell 2016, 38, 118-120. [CrossRef] [PubMed]

54. Mair, A.; Pedrotti, L.; Wurzinger, B.; Anrather, D.; Simeunovic, A.; Weiste, C.; Valerio, C.; Dietrich, K.; Kirchler, T.; Nägele, T.; et al. SnRK1-triggered switch of bZIP63 dimerization mediates the low-energy response in plants. Elife 2015, 4, 1-33. [CrossRef] [PubMed]

55. Frank, A.; Matiolli, C.C.; Viana, A.J.C.; Hearn, T.J.; Kusakina, J.; Belbin, F.E.; Wells Newman, D.; Yochikawa, A.; Cano-Ramirez, D.L.; Chembath, A.; et al. Circadian Entrainment in Arabidopsis by the Sugar-Responsive Transcription Factor bZIP63. Curr. Biol. 2018, 28, 2597-2606.e6. [CrossRef] [PubMed]

56. Kunz, S.; Pesquet, E.; Kleczkowski, L.A. Functional dissection of sugar signals affecting gene expression in Arabidopsis thaliana. PLoS ONE 2014, 9, 1-10. [CrossRef] [PubMed]

57. Veerabagu, M.; Kirchler, T.; Elgass, K.; Stadelhofer, B.; Stahl, M.; Harter, K.; Mira-Rodado, V.; Chaban, C. The Interaction of the Arabidopsis Response Regulator ARR18 with bZIP63 Mediates the Regulation of PROLINE DEHYDROGENASE Expression. Mol. Plant 2014, 7, 1560-1577. [CrossRef]

58. Liu, J.-X.; Srivastava, R.; Che, P.; Howell, S.H. Salt stress responses in Arabidopsis utilize a signal transduction pathway related to endoplasmic reticulum stress signaling. Plant J. 2007, 51, 897-909. [CrossRef]

59. Xue, G.-P.; Way, H.M.; Richardson, T.; Drenth, J.; Joyce, P.A.; McIntyre, C.L. Overexpression of TaNAC69 Leads to Enhanced Transcript Levels of Stress Up-Regulated Genes and Dehydration Tolerance in Bread Wheat. Mol. Plant 2011, 4, 697-712. [CrossRef]

60. Stępień, P.; Kłbus, G. Water relations and photosynthesis in Cucumis sativus L. leaves under salt stress. Biol. Plant. 2006, 50, 610-616. [CrossRef]

61. Cocetta, G.; Mishra, S.; Raffaelli, A.; Ferrante, A. Effect of heat root stress and high salinity on glucosinolates metabolism in wild rocket. J. Plant Physiol. 2018, 231, 261-270. [CrossRef] [PubMed]

62. Urlić, B.; Dumičić, G.; Romić, M.; Ban, S.G. The effect of $\mathrm{N}$ and $\mathrm{NaCl}$ on growth, yield, and nitrate content of salad rocket (Eruca sativa Mill.). J. Plant Nutr. 2017, 40, 2611-2618. [CrossRef]

63. Ashraf, M.; Harris, P.J.C. Photosynthesis under stressful environments: An overview. Photosynthetica 2013, 51, 163-190. [CrossRef]

64. Grossman, R.; Wisenbilt, J. What we know about consumers' color choices. J. Mark. Pract. Appl. Mark. Sci. 1999, 5, 78-88.

65. Bulgari, R.; Cocetta, G.; Trivellini, A.; Vernieri, P.; Ferrante, A. Biostimulants and crop responses: A review. Biol. Agric. Hortic. 2015, 31, 1-17. [CrossRef]

66. Vernieri, P.; Borghesi, E.; Tognoni, F.; Serra, G.; Ferrante, A.; Piaggesi, A. Use of biostimulants for reducing nutrient solution concentration in floating system. Acta Hortic. 2006, 718, 477-484. [CrossRef]

67. Barbieri, G.; Bottino, A.; Di Stasio, E.; Vallone, S.; Maggio, A. Proline and light as quality enhancers of rocket (Eruca sativa Miller) grown under saline conditions. Sci. Hortic. 2011, 128, 393-400. [CrossRef]

68. De Pascale, S.; Maggio, A.; Fogliano, V.; Ambrosino, P.; Ritieni, A. Irrigation with saline water improves carotenoids content and antioxidant activity of tomato. J. Hortic. Sci. Biotechnol. 2001, 76, 447-453. [CrossRef] 
69. Falcinelli, B.; Sileoni, V.; Marconi, O.; Perretti, G.; Quinet, M.; Lutts, S.; Benincasa, P. Germination under moderate salinity increases phenolic content and antioxidant activity in rapeseed (Brassica napus var oleifera Del.) sprouts. Molecules 2017, 22, 1377. [CrossRef]

70. Valifard, M.; Mohsenzadeh, S.; Kholdebarin, B.; Rowshan, V. Effects of salt stress on volatile compounds, total phenolic content and antioxidant activities of Salvia mirzayanii. S. Afr. J. Bot. 2014, 93, 92-97. [CrossRef]

71. Zhou, Y.; Tang, N.; Huang, L.; Zhao, Y.; Tang, X.; Wang, K. Effects of salt stress on plant growth, antioxidant capacity, glandular trichome density, and volatile exudates of schizonepeta tenuifolia briq. Int. J. Mol. Sci. 2018, 19, 252. [CrossRef]

72. Vermerris, W.; Nicholson, R. Phenolic Compounds and their Effects on Human Health. In Phenolic Compound Biochemistry; Springer: Dordrecht, The Netherlands, 2008; pp. 235-255.

73. Yakhin, O.I.; Lubyanov, A.A.; Yakhin, I.A.; Brown, P.H. Biostimulants in Plant Science: A Global Perspective. Front. Plant Sci. 2017, 7, 2049. [CrossRef] [PubMed]

74. Hamilton, J.M.; Fonseca, J.M. Effect of saline irrigation water on antioxidants in three hydroponically grown leafy vegetables: Diplotaxis tenuifolia, eruca sativa, and lepidium sativum. HortScience 2010, 45, 546-552. [CrossRef]

75. Amirjani, M.R. Effect of Salinity Stress on Growth, Sugar Content, Pigments and Enzyme Activity of Rice. Int. J. Bot. 2011, 7, 73-81. [CrossRef]

76. Ashraf, M. Organic substances responsible for salt tolerance in Eruca sativa. Biol. Plant. 1994, 36, $255-259$. [CrossRef]

77. Bolouri-Moghaddam, M.R.; Le Roy, K.; Xiang, L.; Rolland, F.; Van Den Ende, W. Sugar signalling and antioxidant network connections in plant cells. FEBS J. 2010, 277, 2022-2037. [CrossRef] [PubMed]

78. Sami, F.; Yusuf, M.; Faizan, M.; Faraz, A.; Hayat, S. Role of sugars under abiotic stress. Plant Physiol. Biochem. 2016, 109, 54-61. [CrossRef]

79. Ozdener, Y.; Aydin, B.K. The effect of zinc on the growth and physiological and biochemical parameters in seedlings of Eruca sativa (L.) (Rocket). Acta Physiol. Plant. 2010, 32, 469-476. [CrossRef]

80. Iqbal, N.; Nazar, R. Osmolytes and Plants Acclimation to Changing Environment: Emerging Omics Technologies; Iqbal, N., Nazar, R.A., Khan, N., Eds.; Springer: New Delhi, India, 2016; ISBN 978-81-322-2615-4.

81. Slama, I.; Abdelly, C.; Bouchereau, A.; Flowers, T.; Savouré, A. Diversity, distribution and roles of osmoprotective compounds accumulated in halophytes under abiotic stress. Ann. Bot. 2015, 115, 433-447. [CrossRef]

82. Zhou, Q.; Yu, B.J. Accumulation of inorganic and organic osmolytes and their role in osmotic adjustment in NaCl-stressed vetiver grass seedlings. Russ. J. Plant Physiol. 2009, 56, 678-685. [CrossRef]

83. Sah, S.K.; Reddy, K.R.; Li, J. Abscisic Acid and Abiotic Stress Tolerance in Crop Plants. Front. Plant Sci. 2016, 7, 1-26. [CrossRef] [PubMed]

84. Fricke, W.; Akhiyarova, G.; Veselov, D.; Kudoyarova, G. Rapid and tissue-specific changes in ABA and in growth rate in response to salinity in barley leaves. J. Exp. Bot. 2004, 55, 1115-1123. [CrossRef] [PubMed]

85. He, T.; Cramer, G.R. Abscisic acid concentrations are correlated with leaf area reductions in two salt-stressed rapid-cycling Brassica species. Plant Soil 1996, 179, 25-33. [CrossRef]

86. Santamaria, P.; Gonnella, M.; Elia, A.; Parente, A.; Serio, F. Ways of reducing rocket salad nitrate content. Acta Hortic. 2001, 548, 529-536. [CrossRef]

87. Cavaiuolo, M.; Ferrante, A. Nitrates and glucosinolates as strong determinants of the nutritional quality in rocket leafy salads. Nutrients 2014, 6, 1519-1538. [CrossRef]

88. Habermeyer, M.; Roth, A.; Guth, S.; Diel, P.; Engel, K.-H.; Epe, B.; Fürst, P.; Heinz, V.; Humpf, H.-U.; Joost, H.-G.; et al. Nitrate and nitrite in the diet: How to assess their benefit and risk for human health. Mol. Nutr. Food Res. 2015, 59, 106-128. [CrossRef]

89. Urrestarazu, M.; Postigo, A.; Salas, M.; Sánchez, A.; Carrasco, G. Nitrate accumulation reduction using chloride in the nutrient solution on lettuce growing by NFT in semiarid climate conditions. J. Plant Nutr. 1998, 21, 1705-1714. [CrossRef]

90. Amanda, A.; Ferrante, A.; Valagussa, M.; Piaggesi, A. Effect of biostimulants on quality of baby leaf lettuce grown under plastic tunnel. Acta Hortic. 2009, 807, 407-412. [CrossRef]

91. Disciglio, G.; Frabboni, L. Applying Natural Fertiliers to Herbaceous Crops. J. Life Sci. 2014, 8, 504-510. 
92. Bulgari, R. Studies of Quality and Nutrient use Efficiency in Vegetable Crops Grown under Different Sustainable Cropping System. Ph.D. Thesis, Dipartimento di Scienze Agrarie e Ambientali-Produzione, Territorio, Agroenergia, Università degli studi di Milano, Milan, Italy, 2018.

93. Livak, K.J.; Schmittgen, T.D. Analysis of Relative Gene Expression Data Using Real-Time Quantitative PCR and the 2- $\Delta \Delta$ CT Method. Methods 2001, 25, 402-408. [CrossRef]

94. Strasser, R.J.; Tsimilli-Michael, M.; Srivastava, A. Analysis of the Chlorophyll a Fluorescence Transient Reto. In Chlorophyll a Fluorescence: A Signature of Photosynthesi; Papageorgiou, G.C., Govindjee, J., Eds.; Kluwer Academic Publishers Press: Amsterdam, The Netherlands, 2004; pp. 321-362.

95. Lichtenthaler, H.K. Chlorophylls and carotenoids: Pigments of photosynthetic biomembranes. Methods Enzymol. 1987, 148, 350-382.

96. Ke, D.; Saltveit, M.E. Wound-induced ethylene production, phenolic metabolism and susceptibility to russet spotting in iceberg lettuce. Physiol. Plant. 1989, 76, 412-418. [CrossRef]

97. Klein, A.O.; Hagen, C.W. Anthocyanin production in detached petals of impatiens balsamina L. Plant Physiol. 1961, 36, 1-9. [CrossRef] [PubMed]

98. Cataldo, D.A.; Maroon, M.; Schrader, L.E.; Youngs, V.L. Rapid colorimetric determination of nitrate in plant tissue by nitration of salicylic acid. Commun. Soil Sci. Plant Anal. 1975, 6, 71-80. [CrossRef]

99. Miller, G.L. Use of Dinitrosalicylic Acid Reagent for Determination of Reducing Sugar. Anal. Chem. 1959, 31, 426-428. [CrossRef]

100. Yemm, E.W.; Willis, A.J. The estimation of carbohydrates in plant extracts by anthrone. Biochem. J. 1954, 57, 508. [CrossRef]

101. Heath, R.L.; Packer, L. Photoperoxidation in isolated chloroplasts. Arch. Biochem. Biophys. 1968, 125, $189-198$. [CrossRef]

102. Du, Z.; Bramlage, W.J. Modified thiobarbituric acid assay for measuring lipid oxidation in sugar-rich plant tissue extracts. J. Agric. Food Chem. 1992, 40, 1566-1570. [CrossRef]

103. Trivellini, A.; Lucchesini, M.; Ferrante, A.; Carmassi, G.; Scatena, G.; Vernieri, P.; Mensuali-Sodi, A. Survive or die? A molecular insight into salt-dependant signaling network. Environ. Exp. Bot. 2016, 132, 140-153. [CrossRef]

(C) 2019 by the authors. Licensee MDPI, Basel, Switzerland. This article is an open access article distributed under the terms and conditions of the Creative Commons Attribution (CC BY) license (http://creativecommons.org/licenses/by/4.0/). 